Article

\title{
Techno-Economic Bottlenecks of the Fungal Pretreatment of Lignocellulosic Biomass
}

\author{
Juliana Vasco-Correa ${ }^{(1)}$ and Ajay Shah *(i) \\ Department of Food, Agricultural and Biological Engineering, Ohio Agricultural Research and Development \\ Center, The Ohio State University, 1680 Madison Ave., Wooster, OH 44691-4096, USA; \\ vascocorrea.1@buckeyemail.osu.edu \\ * Correspondence: shah.971@osu.edu; Tel.: +1-330-263-3858
}

Received: 15 February 2019; Accepted: 26 March 2019; Published: 29 March 2019

check for

updates

\begin{abstract}
Fungal pretreatment is a biological process that uses rotting fungi to reduce the recalcitrance and enhance the enzymatic digestibility of lignocellulosic feedstocks at low temperature, without added chemicals and wastewater generation. Thus, it has been presumed to be low cost. However, fungal pretreatment requires longer incubation times and generates lower yields than traditional pretreatments. Thus, this study assesses the techno-economic feasibility of a fungal pretreatment facility for the production of fermentable sugars for a $75,700 \mathrm{~m}^{3}$ (20 million gallons) per year cellulosic bioethanol plant. Four feedstocks were evaluated: perennial grasses, corn stover, agricultural residues other than corn stover, and hardwood. The lowest estimated sugars production cost $(\$ 1.6 / \mathrm{kg})$ was obtained from corn stover, and was $4-15$ times as much as previous estimates for conventional pretreatment technologies. The facility-related cost was the major contributor (46-51\%) to the sugar production cost, mainly because of the requirement of large equipment in high quantities, due to process bottlenecks such as low sugar yields, low feedstock bulk density, long fungal pretreatment times, and sterilization requirements. At the current state of the technology, fungal pretreatment at biorefinery scale does not appear to be economically feasible, and considerable process improvements are still required to achieve product cost targets.
\end{abstract}

Keywords: biorefinery; fungal pretreatment; lignocellulosic biomass; process model; techno-economic analysis

\section{Introduction}

Cellulosic biorefineries are anticipated to produce a collection of renewable biofuels and bioproducts from lignocellulosic biomass to allow a significant displacement of petroleum-derived fuels and chemicals [1]. The main sources for lignocellulosic biomass include forestry resources, agricultural residues, and energy crops, such as switchgrass and Miscanthus [2]. A sustainable bioeconomy would require the use of different types of feedstocks, subject to availability and price, in order to meet the demands of renewable fuels and products [2]. However, the composition and physico-chemical properties of feedstocks vary significantly with the feedstock type and source. Thus, different types of feedstocks require different processing conditions and generate distinct product yields [3].

Lignocellulosic biomass is mostly composed of cellulose, hemicellulose and lignin. Most of the products in a cellulosic biorefinery are generated via fermentation of the sugars released from cellulose and hemicellulose by enzymatic saccharification. However, lignocellulosic biomass is highly recalcitrant and requires pretreatment prior to enzymatic hydrolysis to increase feedstock digestibility and allow a substantial sugar recovery. Pretreatment has been considered one of the main contributors to the cost of final products in cellulosic biorefineries [4]. Conventionally, pretreatments are performed at high temperature and pressure, use harsh chemicals such as acids or bases, and require high amounts 
of water [5]. Additionally, most commercially available pretreatments, such as dilute acid and liquid hot water pretreatment, require an additional detoxification step, because their severe conditions promote the generation of compounds derived from lignocellulose, such as furans, weak acids and aromatic compounds, which could inhibit fermentative microorganisms, such as yeast and bacteria [6].

A series of alternative methods have been proposed to reduce the severity of the conditions required for biomass fractionation and pretreatment. Use of extrusion, microwaves, ultrasound, or pulse electric field has shown to improve the biomass pretreatment process and allowed for the use of milder pretreatment conditions [7]. Biomass pretreatment with aqueous organic solvents (organosolv) [8,9], ozone (ozonolysis) [10], ionic liquids [11,12], or deep eutectic solvents [13] has shown promising results in biomass fractionation $[14,15]$. However, concerns about the costs, handling, and recovery of the chemicals present limitations in their large-scale applicability $[14,16]$.

Fungal pretreatment is as an alternative to conventional pretreatments that is performed at 25-30 ${ }^{\circ} \mathrm{C}$, atmospheric pressure, in solid-state with low water use, and without added chemicals that can be corrosive and would need disposal or recovery [17]. Fungal pretreatment is generally performed using wood-rotting fungi, such as white-, brown-, or soft-rot fungi, due to their ability to modify the components of the lignocellulosic biomass. Brown-rot fungi mainly degrade cellulose and hemicellulose, with little modification to the lignin, which is detrimental for the production of fermentable sugars [18]. Some soft-rot fungi have shown the ability to degrade lignin, while most of soft-rot fungi can only slightly modify it, while significantly degrading the structural carbohydrates [19]. White-rot fungi are preferred for fungal pretreatment due to their ability to completely mineralize lignin under aerobic conditions and, in some cases, doing so preferentially over cellulose [20]. The mild conditions of the fungal pretreatment are unlikely to produce microbial inhibitory compounds, and thus post-pretreatment washing and/or detoxification are not required. Additionally, fungal pretreatment is effective at larger feedstock particle sizes than most conventional pretreatments [17]. However, fungal pretreatment has some potential disadvantages compared to traditional pretreatments, including long reaction times (several weeks compared to hours), lower sugar yields (maximum sugar yields around $75 \%$ vs. $>90 \%$ ), and feedstock sterilization requirements [18].

The fungal pretreatment of woody and herbaceous feedstocks has been performed using a variety of white-rot fungal strains. The fungal pretreatment of hardwoods such as poplar, willow, and rubberwood has resulted in 18-30\% lignin degradation and a glucose yield of 17-55\%, using strains such as Ceriporiopsis subvermispora, Echinodontium taxoddi, Trametes orientalis, and Trametes velutina [21-26]. The fungal pretreatment of herbaceous agricultural wastes such as wheat, paddy, canola, barely and rice straw, and sorghum and sugarcane bagasse, has reported sugar yields between 25 and $70 \%$ with 20-52\% lignin degradation, using white-rot fungi such as Pleurotus ostreatus, Trametes versicolor, and C. subvermispora [27-38]. Similar results have been found after the fungal pretreatment of switchgrass and Miscanthus with C. subvermispora and Pycnoporus sp. SYBC-L3 $[22,39,40]$. The fungal pretreatment of corn stover has shown particularly promising results, producing sugar yields of approximately $45-75 \%$ and up to $60 \%$ lignin degradation, with Cyathus stercoreus, Pycnoporus sanguineus, Phlebia brevispora, Trametes hirsuta, Phanerochaete chrysosporium, I. lacteus, and C. subvermispora [22,33,41-46].

Several authors have claimed that fungal pretreatment is a low-cost technology due to the use of a solid-state process with low energy and chemical inputs $[17,20,47,48]$. However, Baral and Shah [49] found that, for a corn stover-to-butanol biorefinery, biological pretreatment required a higher capital investment than dilute acid, steam explosion, and ammonia fiber expansion pretreatments. Considerations about the sterility required for the effectiveness of the fungal pretreatment, the long residence time and its implications into the equipment size, the substantial amount of heat generated by the fungal metabolic rate, and the high aeration rate needed for effective delignification could have an important influence in the techno-economic analysis of the fungal pretreatment process at commercial scale, and have yet to be studied.

The purpose of this work is to compare the techno-economic feasibility of commercial scale fungal pretreatment for the production of fermentable sugars from different lignocellulosic feedstocks. Corn 
stover, herbaceous energy crops, agricultural residues other than corn stover, and woody feedstocks are considered, based on fungal pretreatment literature. The total cost of fermentable sugars produced from each feedstock is estimated, and the effect of process parameters on this cost is evaluated to determine the key potential bottlenecks of the fungal pretreatment process at commercial scale.

\section{Materials and Methods}

\subsection{Process Modeling}

A process model for the transformation of lignocellulosic feedstocks into fermentable sugars using fungal pretreatment and enzymatic hydrolysis was developed using SuperPro Designer software v.9.5 (Intelligen Inc., Scotch Plains, NJ, USA). The process facility capacity was 135,000 metric ton (t) sugars/year, in order to supply a cellulosic biorefinery producing 75,700 $\mathrm{m}^{3}$ of ethanol per year (20 million gallons/year), assuming $90 \%$ and $80 \%$ of the theoretical conversion of glucose and xylose into ethanol, respectively [50]. The fungal pretreatment-based facility included feedstock storage, sterilization by autoclaving, solid-state fungal pretreatment, and enzymatic hydrolysis (Figure 1). A process flow diagram was completed, and the data and expressions necessary to perform material and energy balances, equipment capacity limitations, purchase price, and installation and maintenance expenses were included in the model. The material and energy balances were used to determine the required equipment size and quantity, raw materials, and utilities, as well as other direct and indirect costs.

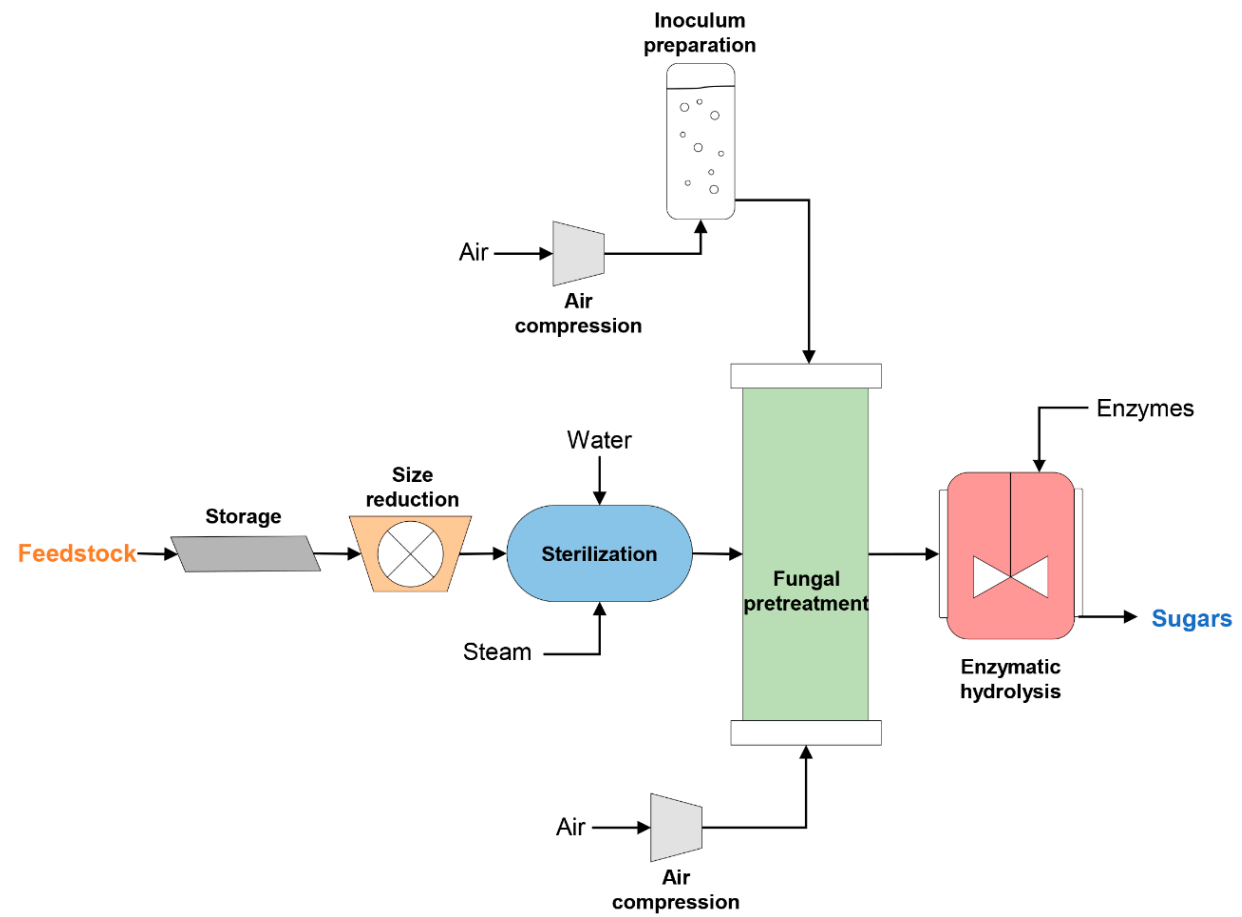

Figure 1. Overview of the fungal pretreatment process for the production of fermentable sugars.

\subsubsection{Data Collection}

A collection of recent experimental studies on the fungal pretreatment of lignocellulosic biomass using white-rot fungi was selected as data source for the fungal pretreatment conditions and performance. These studies were classified according to the feedstock used into four categories: hardwood [21-26,51], perennial grasses (switchgrass and Miscanthus) [22,39,40,52,53], corn stover [22,33,41-46], and agricultural residues other than corn stover (including wheat, rice, canola, and barley straw) [27-38]. Corn stover was evaluated independently from other agricultural residues because a significant body of literature was found for the fungal pretreatment of this particular 
substrate compared to other agricultural residues, and because there is a particular interest in the use of corn stover as a biorefinery feedstock in the U.S. due to its availability [2]. These studies were selected because they showed experimental results of the fungal pretreatment of lignocellulosic feedstocks using white-rot fungi in solid-state conditions, and subsequent enzymatic hydrolysis with commercial cellulases, reporting the corresponding sugar yields. The white-rot fungi used in these studies included C. stercoreus, C. subvermispora, E. taxoddi, P. ostreatus, Pycnoporus sp. SYBC-L3, P. sanguineus, P. brevispora, P. chrysosporium, T. orientalis, T. velutina, T. versicolor, and T. hirsuta. Different cellulase cocktails were used for the enzymatic saccharification of the fungal pretreated feedstocks, including Celluclast $1.5 \mathrm{~L}$ plus Novozyme 188 and Cellic CTec2 plus Cellic HTec2 from Novozymes (Denmark), Accelerase 1500 from Genencor (DuPont, Rochester, NY, USA), and Cellulase Y-NC from Yakult Pharmaceutical Industry (Tokyo, Japan). Enzyme loading (10-40 FPU/g substrate), enzymatic saccharification time (16-96 h), and solid loading (1-10\%) varied among the studies surveyed (Table S1) [21-46,51-53].

Composition of the feedstocks (Table 1), fungal pretreatment conditions (Table 2), component degradation during fungal pretreatment, and sugar yields (Table 3) were obtained from these studies. The average values for each feedstock were used as inputs for the modeling (Figure 2) and the maximum and minimum values obtained from this set of studies were used for the sensitivity analysis, as described in Section 2.3 (Table S1). Feedstock prices at biorefinery gate and feedstock moisture content were based on the Billion Ton Report [2], and other feedstock properties and sources are reported in Table 1.

Table 1. Feedstock composition and properties used for the process model.

\begin{tabular}{|c|c|c|c|c|c|c|c|c|c|}
\hline \multirow{3}{*}{ Property } & \multirow{3}{*}{ Units } & \multicolumn{8}{|c|}{ Feedstock } \\
\hline & & \multicolumn{2}{|c|}{ Grasses } & \multicolumn{2}{|c|}{ Corn Stover } & \multicolumn{2}{|c|}{ Ag. Residues } & \multicolumn{2}{|c|}{ Hardwood } \\
\hline & & Value & Ref. & Value & Ref. & Value & Ref. & Value & Ref. \\
\hline Bulk density (baled) & $\mathrm{kg} / \mathrm{m}^{3}$ & 215 & [54] & 220 & {$[55,56]$} & 180 & {$[57,58]$} & $\mathrm{N} / \mathrm{A}$ & $\mathrm{N} / \mathrm{A}$ \\
\hline Bulk density (grinded) & $\mathrm{kg} / \mathrm{m}^{3}$ & 160 & {$[59,60]$} & 125 & {$[61]$} & 110 & {$[62]$} & 320 & [63] \\
\hline \multicolumn{10}{|l|}{ Composition } \\
\hline Cellulose * & & 34.9 & & 38.1 & & 36.3 & \multirow{3}{*}[27-31,33-38]{} & 35.2 & \multirow{4}{*}[22-26,51,53]{} \\
\hline Hemicellulose * & & 20.8 & {$[22,40$,} & 25.0 & {$[22,33$} & 24.5 & & 16.6 & \\
\hline Lignin * & & 21.5 & $52,53]$ & 19.0 & $41-46]$ & 20.5 & & 23.9 & \\
\hline Ash * & & 3.7 & & 6.0 & & 3.5 & & 3.6 & \\
\hline Moisture & $\%$ & 15 & [2] & 20 & {$[2,50]$} & 15 & [2] & 50 & {$[57,63]$} \\
\hline $\begin{array}{c}\text { Cost } \\
\text { (facility gate) }\end{array}$ & $\underset{t}{\$ / \text { dry }}$ & 97.1 & [2] & 97.4 & [2] & 97.4 & {$[2]$} & 76.3 & {$[2]$} \\
\hline Specific heat & $\mathrm{J} / \mathrm{kg} \cdot \mathrm{K}$ & 1394 & [64] & 1395 & {$[64]$} & 1356 & [64] & 1330 & [64] \\
\hline
\end{tabular}

* Dry basis; values correspond to average from surveyed literature and ranges are provided in Table S1.

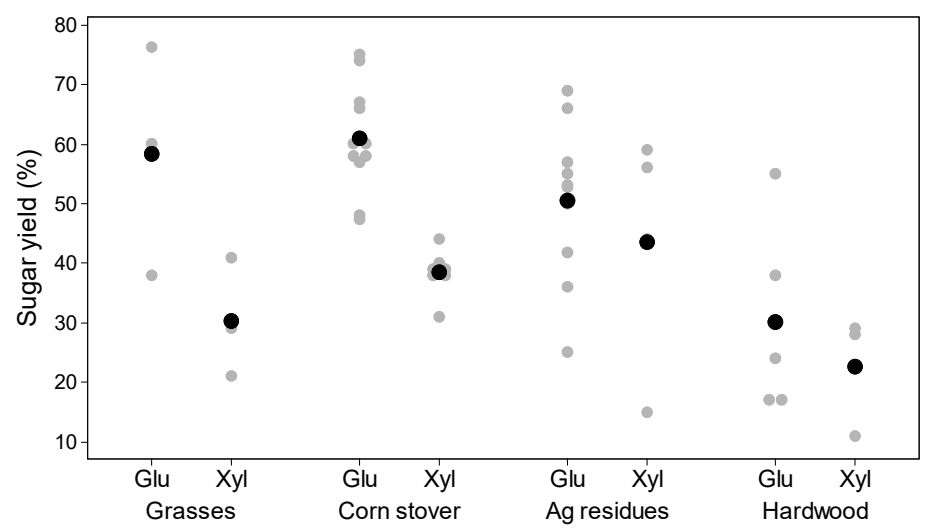

Figure 2. Glucose (Glu) and xylose $(\mathrm{Xyl})$ yields at the end of the process, as a percentage of the glucose and xylose present in the original feedstock, respectively. Data from: [21-46,51-53]. Grey circles represent individual data from literature. Black circles represent the average used for process modeling. 


\subsubsection{Feedstock Preparation and Preprocessing}

For herbaceous feedstocks (corn stover, grasses, and other agricultural residues), it was assumed that the feedstock was delivered as large rectangular bales $(2.4 \times 1.2 \times 0.9 \mathrm{~m})$ to the biorefinery, and stored for an average time of 5 days before being processed [2]. Herbaceous feedstocks were debaled and grinded using a hammer mill with a 50.8- $\mathrm{mm}$ ( $2 \mathrm{in}$ ) screen [39]. Wood was assumed to be delivered as chips of less than $15 \mathrm{~mm}$ in size and no further size reduction was necessary, since it has been shown that fungal pretreatment is effective at that particle size [22], and a particle size too small could cause high compaction and restrict the air flow during fungal pretreatment [17]. The bulk density of the materials (Table 1) was incorporated throughout the model to calculate the volume occupied and, thus, the equipment capacity required. With the addition of water and other components through the process, the bulk density of the wet mixture was calculated at each step [59].

Comminuted feedstock was transported using a bucket elevator and belt conveyor into horizontal batch autoclaving units for sterilization with saturated steam (Table 2). The feedstock's specific heat (Table 1) was used to calculate the steam flow required for sterilization [64]. Feedstock sterilization was included because previous work with certain fungal strains has shown that fungal pretreatment underperformed under unsterilized conditions [53] and all the fungal pretreatment studies used as data source included feedstock sterilization prior to fungal inoculation [21-46,51-53]. Water was added to the feedstocks before autoclaving to adjust the initial moisture content of the fungal pretreatment to $75 \%$. The sterilized feedstock was transported out of the autoclave by a screw conveyor into the fungal pretreatment bioreactors.

Table 2. Process conditions used for modeling of the fungal pretreatment-based facility for the production of fermentable sugars.






\subsubsection{Fungal Pretreatment Unit}

Fungal pretreatment was performed in packed-bed bioreactors, which is the most common design for solid-state aerobic fermentation with microorganisms that are sensitive to shear stress [72], such as white-rot fungi [75]. Packed-bed bioreactors were selected because of the need to keep the sterilized conditions during the fungal pretreatment [53]. The feedstock was inoculated with fungal mycelium grown on liquid culture in an air-lift fermenter (Table 2), and the bioreactor was aerated from the bottom with compressed air (Figure 1). Mechanical aeration was required to supply the high oxygen requirement for the biomass delignification during fungal pretreatment, and to help dissipate some of the metabolic heat produce by the white-rot fungi [76]. The temperature of the bioreactors (both the packed-bed bioreactor and the air-lift fermenter) was kept at $28{ }^{\circ} \mathrm{C}$ using cooling water, due to the heat produced by the metabolism of the white-rot fungi (Table 2). Other conditions and parameters used were as included in Table 2. Degradation rates of structural carbohydrates and lignin during fungal pretreatment due to the fungal metabolism and lignin mineralization were based on the fungal pretreatment literature collection (Section 2.1.1) and are reported in Table 3.

Table 3. Component degradation (\%) during fungal pretreatment and overall sugar yields (\%) after enzymatic hydrolysis for the fungal pretreatment-based facility.

\begin{tabular}{ccccc}
\hline & Grasses & Corn Stover & Ag. Residues & Hardwood \\
\hline Fungal pretreatment & & & & \\
\hline Lignin degradation $^{\text {a }}$ & 20.8 & 41.3 & 33.1 & 20.2 \\
Cellulose degradation $^{\text {a }}$ & 1.0 & 17.3 & 33.9 & 5.2 \\
Hemicellulose degradation $^{\text {a }}$ & 12.8 & 40.3 & 38.3 & 18.3 \\
Total solids degradation $^{\mathrm{b}}$ & 13.0 & 24.8 & 30.4 & 14.9 \\
\hline Enzymatic hydrolysis & & & & \\
\hline Glucose yield $^{\mathrm{c}}$ & 58 & 61 & 51 & 30 \\
Xylose yield $^{\mathrm{c}}$ & 30 & 39 & 39 & 23 \\
\hline
\end{tabular}

Data from: grasses [22,39,40,52,53], corn stover [22,33,41-46], agricultural residues other than corn stover [27-38], and hardwood [21-26,51]. ${ }^{\text {a }}$ Percentage of component degradation due to the fungal pretreatment process, based on the initial amount of said component in the original feedstock entering the fungal pretreatment unit. ${ }^{\mathrm{b}}$ Total solids degradation aggregated the degradation of the components described above (lignin, cellulose and hemicellulose) plus the degradation of additional components, such as extractives, as a fraction of the original dry matter content. These components are lost mostly in the form of $\mathrm{CO}_{2}$ and water [17]. ${ }^{\mathrm{c}}$ Sugar yield: (sugar released after enzymatic hydrolysis $[\mathrm{kg}] /$ sugar in the original feedstock entering the facility $[\mathrm{kg}])^{*} 100$.

\subsubsection{Enzymatic Hydrolysis Unit}

After fungal pretreatment, the biomass was transferred using a screw conveyor directly into stirred tank reactors for enzymatic hydrolysis. No washing or detoxification step was included. Enzymatic saccharification was performed using commercial hydrolases at an enzyme loading rate of $20 \mathrm{~g}$ of protein $/ \mathrm{kg}$ of cellulose [74]. The price of the enzymes was estimated according to previous studies [73]. Enzymatic saccharification conditions used are reported in Table 2 and the overall sugar yields were based on the fungal pretreatment literature collection (Section 2.1.1), and are included in Table 3.

\subsection{Economic Analysis}

Parameters to estimate capital and operating costs were determined according to previous studies (Table A1) [49,50,77-79]. The facility was considered to operate 330 days per year, working $24 \mathrm{~h}$ per day $[49,50]$. The cost of each equipment was based on the literature and on the built-in data from the modeling software, as shown in Table A2. The equipment cost obtained from the literature was adjusted to the analysis year and the modelled scale using the power law with exponent 0.6 , unless a different exponent was suggested in the literature [80].

Total capital investment (TCI) was determined as the sum of direct fixed capital (DFC), working capital, and start-up cost. DFC included total plant direct cost (TPDC), total plant indirect cost 
(TPIC), and contractor's fee and contingency. TPDC comprised equipment cost, installation, piping, instrumentation, insulation, electrical, buildings, yard improvement, and auxiliary facilities. TPIC was estimated as the cost of the engineering and construction. Working capital included cost of raw materials, labor and utilities needed to run the plant for 30 days. Start-up cost was estimated as $5 \%$ of the DFC. Annual operating cost included cost of raw materials, labor, utilities, and facility-related, and laboratory- and quality control-related costs.

\subsection{Sensitivity Analysis}

Sensitivity analysis was performed to evaluate the effect of changes in process parameters over the sugar production cost. Parameters evaluated were glucose and xylose yields; fungal pretreatment time, temperature, and moisture content; feedstock and enzyme costs; feedstock bulk density; enzymatic hydrolysis solid loading and time; enzyme dosage; and inoculum incubation time. Minimum and maximum values for each parameter were selected from literature. Each parameter was varied independently in the process model for each feedstock, and the mass and energy balances and economic analysis were re-calculated in each case to estimate the sugar production cost.

The effects of eliminating the sterilization step and performing other process improvements based on the sensitivity analysis were evaluated for the feedstock with the lower sugar production cost under the baseline conditions. The changes to the process model were performed in sequence, in order to estimate the potential reduction of the sugar production cost under these conditions.

\section{Results and Discussion}

\subsection{Material and Energy Balances}

Approximately 3 dry $t$ of corn stover were needed to produce $1 \mathrm{t}$ of fermentable sugars (glucose and xylose) in the fungal pretreatment facility, while almost 4 dry $t$ of grasses or agricultural residues, and approximately $7 \mathrm{dry} t$ of hardwood, were required for the same purpose (Figure 3). Water was added in the feedstock preparation step to adjust for the desired initial moisture content for the fungal pretreatment. A dry matter loss of $2 \%$ was included during the sterilization step, as reported previously [22]. There was a slight increase in dry matter after enzymatic hydrolysis due to the chemical incorporation of water-derived hydrogen and oxygen in the sugars during the hydrolysis of carbohydrates. Two streams were derived from the enzymatic hydrolysis: a liquid stream including the soluble sugars, and a solid waste stream, mostly composed of lignin and recalcitrant carbohydrates. Generally, the solid waste stream is burned for heat and power, but this operation and its potential economic benefits were not included in the model due to difficulties predicting the stream properties for each feedstock.

The higher amount of hardwood required to produce $1 \mathrm{t}$ of fermentable sugars, in comparison to the other feedstocks, increased the requirements of water, inoculum, and enzymes in this process. Even though hardwood had higher moisture content than the other feedstocks evaluated (Table 1), it also required a higher amount of total water to reach the $75 \%$ moisture content for the fungal pretreatment process due to the higher mass input to the process. The fungal pretreated hardwood also required 1.7 to 2.7 times as much enzyme for hydrolysis as the other feedstocks (Figure 3).

The sugar concentration of the liquid stream after enzymatic hydrolysis varied considerably between feedstocks. Corn stover produced a higher total sugar concentration of approximately $95 \mathrm{~g} / \mathrm{L}$, followed by $74 \mathrm{~g} / \mathrm{L}$ from agricultural residues, $72 \mathrm{~g} / \mathrm{L}$ from grasses, and only around $30 \mathrm{~g} / \mathrm{L}$ from hardwood (Figure 3). Since the cost of sugar recovery was not included in the model, the differences due to the sugar concentrations were not accounted. However, it is clear that a higher sugar concentration would be preferable for fermentation downstream and may generate additional economic benefits. 


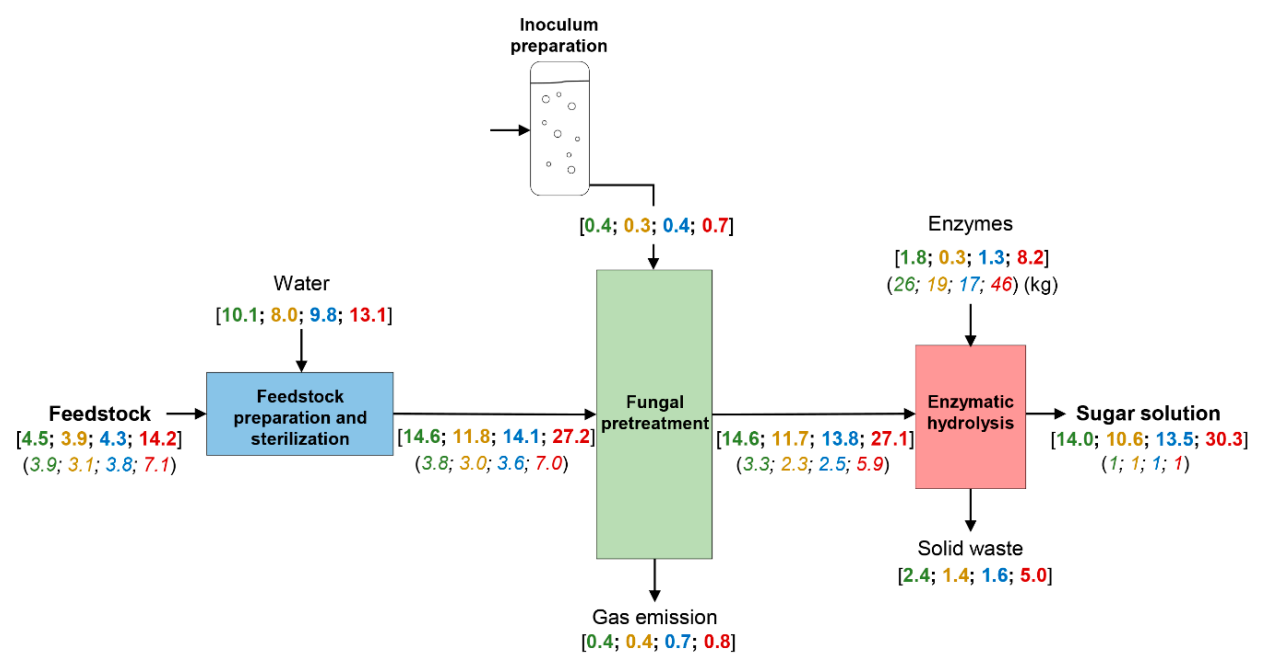

Figure 3. Mass balance for the production of $1 \mathrm{t}$ of fermentable sugars (combination of glucose and xylose) in the fungal pretreatment-based facility. All values in $t$, unless otherwise stated. Values in [] and bold represent the whole stream (top line), while values in () and italics represent the equivalent flows in terms of dry matter (bottom line). Different colors represent different feedstocks: grasses (green), corn stover (yellow), agricultural residues other than corn stover (blue), and hardwood (red). Notes: no dry matter was shown in the inoculum stream, because values are lower than the significant figures. Values might not balance exactly due to rounding. Aeration streams are not shown.

\subsection{Process Economics}

Total capital investment ranged from 700 million dollars for grasses to 1.2 billion dollars for hardwood (Figure 4), which was 5- to 10-fold of that estimated previously for conventional pretreatments at similar scale [49]. This high capital investment was mostly influenced by the large investments required for equipment purchasing, and other expenses that were proportional to the equipment cost, such as installation, piping, instrumentation, construction, and engineering (Table S3). The high equipment expenses were due mostly to the large size of the equipment needed, and the requirement of several units for each of the key processes, such as fungal pretreatment, enzymatic hydrolysis, and autoclaving (Tables A2 and A4). Between $66-70 \%$ of the equipment expenses corresponded to the cost of the packed-bed bioreactors used for the fungal pretreatment process (Table A4), which was primarily due to longer residence times.



Figure 4. Capital investment required for the fungal pretreatment-based facility for the production of fermentable sugars. 
The estimated production cost of the fermentable sugars in the fungal pretreatment facility was $\$ 1.6-\$ 2.8 / \mathrm{kg}$ sugars (Figure 5). These costs were 4- to 15 -fold of the previously reported sugar production costs using conventional pretreatments [49,50], and 5- to 8-fold the average market price of sugar as a commodity in 2017 [81]. Fungal pretreatment has been believed to be a low cost pretreatment due to the low energy and chemical requirements $[17,20,47,48]$. However, this analysis estimated that the fungal pretreatment cost was considerably higher than conventional pretreatments and approximately one order of magnitude over that expected for a pretreatment to be commercially feasible [50].

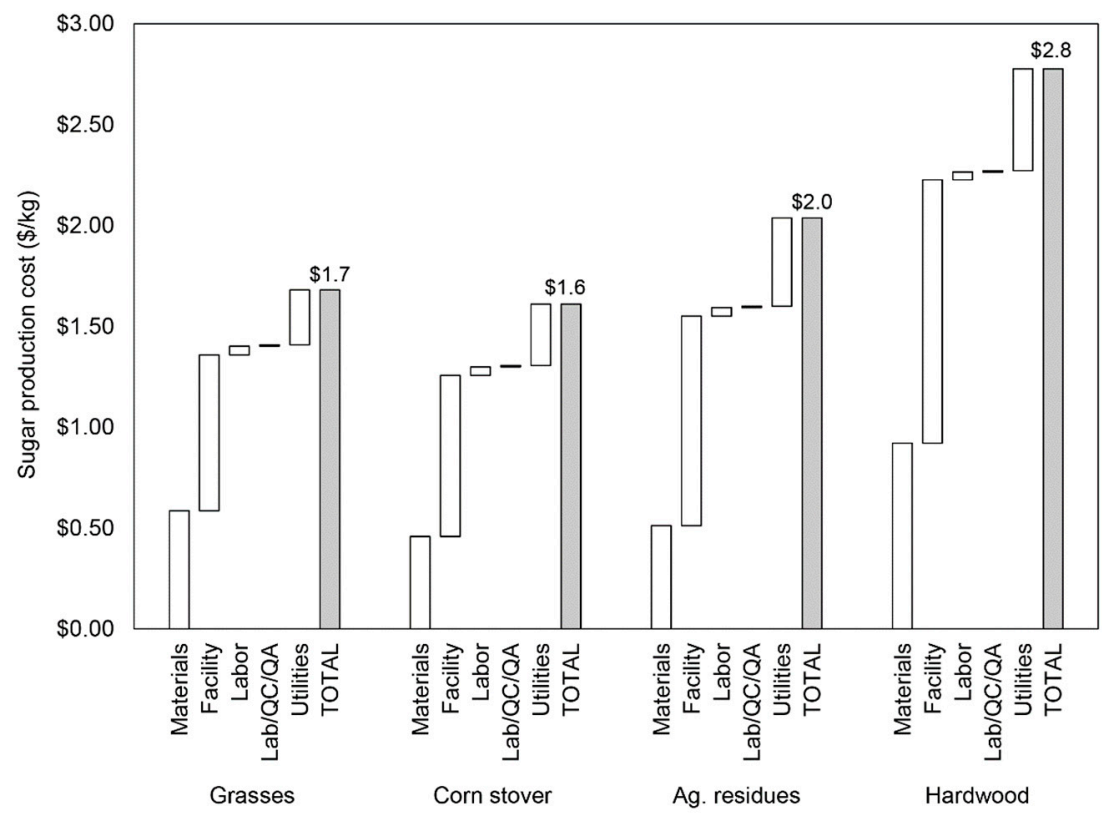

Figure 5. Fermentable sugar production cost in the fungal pretreatment-based facility.

The fungal pretreatment-based facility using corn stover as feedstock generated the lowest sugar production cost, followed by grasses, other agricultural residues, and hardwood (Figure 5). These results were driven mostly by differences in sugar yields (Table 3). Corn stover had higher glucose and xylose yields, but also the highest content of cellulose and hemicellulose compared to other feedstocks (Table 1), which directly benefited the economics of its processing. Additionally, corn stover is readily available in the U.S. and used for the pioneer cellulosic biorefineries [2]. Agricultural residues had the highest sugar production cost of the herbaceous feedstocks. This was due to the lower sugar yields (Table 3) and the lower bulk density of most of these feedstocks (Table 1), a phenomenon that has been described previously [82].

The highest sugar production cost was obtained with hardwood, and it was between 35 and 75\% higher than those from the herbaceous feedstocks (Figure 5). Hardwood had a lower feedstock cost and a considerably higher bulk density, thus requiring less bioreactor space to pretreat the same amount of feedstock compared to herbaceous feedstocks. In addition, hardwood was delivered with a higher moisture content and required less water per mass of feedstock to adjust the level to those appropriate for fungal pretreatment. However, hardwood is more recalcitrant than the herbaceous feedstocks, and the sugar yields were lower (Table 3). Thus, approximately two-times the amount of hardwood was needed to produce the same amount of fermentable sugars compared to the herbaceous feedstocks. This required a much bigger facility with more bioreactors and autoclaves, and a higher amount of resources, such as enzymes, water, and utilities. Labor, however, was slightly lower for hardwood than the rest of the feedstocks, because hardwood was delivered as woodchips at the desired particle size, thus avoiding the milling operation at the beginning, and the labor related to that operation (Table A3). 
The total annual operation cost ranged from 218 to 374 million dollars, depending on the feedstock (Table A3). These values were 2- to 3.5-fold those previously obtained for conventional pretreatment, and similar to that reported for biological pretreatment [49]. Facility related costs comprised $46-51 \%$ of that cost, materials corresponded to $25-35 \%$, and utilities represented $16-21 \%$ of the total sugar cost (Figure 5).

The high facility-related cost was mostly attributed to the high capital investment required for the fungal pretreatment-based facility (Figure 4), which in turn was driven by the equipment purchase cost, mostly the packed-bed bioreactors for the fungal pretreatment and the enzymatic hydrolysis tanks. The high demand for fungal pretreatment bioreactors (Table A4), which was also observed previously [49], was mainly due to the long residence time for fungal pretreatment. While conventional pretreatments are generally performed in minutes or hours, fungal pretreatment usually requires at least 2-3 weeks to significantly increase feedstock digestibility $[27,41,83]$. Reducing the fungal pretreatment time is one of the biggest challenges to improve this process economic feasibility.

The materials cost was the second main contributor to the sugar production cost (Figure 5). The feedstock cost constituted $18-22 \%$ of the total sugar production cost (Table A3). This contrasted with most economic studies of cellulosic biorefineries, which have found that the feedstock cost was the major contributor to the production cost in cellulosic biorefineries, with a share of over $50 \%$ of the products cost $[16,49,50,79]$. For biological pretreatment, a feedstock cost share of approximately $35 \%$ of the total sugar production cost was previously estimated [49]. In the current analysis, the feedstock cost constituted $18-22 \%$ of the sugar production cost (Table A3). However, the feedstock cost remains an important portion of the product cost and it is still one of the major bottlenecks for the feasibility of cellulosic refineries [84]. The enzyme cost corresponded to $22-33 \%$ of the total material cost, which was equivalent to $6-11 \%$ of the total sugar production cost (Table A3), similarly to previous reports $[49,50,85]$. However, continuous advances in commercial hydrolytic enzymes could have an impact on the cost and enzyme dosage and thus likely reducing the share of enzyme cost on the sugar product cost on the fungal pretreatment-based facility.

Utilities accounted for more than a fifth of the annual operating cost (Figure 5). Service water constituted $45-55 \%$ of the total utility expenses for the facility (Table 4). Even though important quantities of superheated steam were used for feedstock sterilization, the highest contribution to the utility expenses was water used to cool down the feedstocks after sterilization and to maintain the temperature of the bioreactors. Since the optimal temperature of the fungal pretreatment is only $28^{\circ} \mathrm{C}$ and the sterilization was performed at $121^{\circ} \mathrm{C}$, reduction of the sterilized feedstock temperature was required prior to fungal inoculation. Additionally, since the fungal pretreatment was performed in solid-state fermentation in large packed-bed bioreactors without agitation, the dissipation of the heat produced by the fungal metabolism had a high demand of chilled water. At small scale, the heat produced during the fungal pretreatment is easy to dispel; but at a larger scale, a lower transfer area per volume ratio constitutes an impediment to heat dissipation. Heat recovery has a low potential to improve the process economics due to low temperature gradients and, thus, it was not included in this analysis. Alternative ways of dissipating the heat, such as adjusting the temperature and moisture content of the compressed air, could be explored. However, this would likely cause an important amount of water vaporization, and it would need to be experimentally evaluated to ensure that the fungal pretreatment is still effective under those conditions. The optimal temperature for white-rot fungi $\left(25-30^{\circ} \mathrm{C}\right)$ is lower than that for other fungi. Fungi used for different applications have been selected to withstand higher temperatures than the original strains [86]. The possibility of identifying or engineering thermophilic fungi capable of lignin degradation would benefit the feasibility of the fungal pretreatment process at commercial scale by allowing the implementation of the fungal pretreatment at a higher temperature and reducing the need for a cooling agent. 
Table 4. Labor and utilities requirements for the fungal pretreatment-based facility producing fermentable sugars (cost in million dollars).

\begin{tabular}{lcccccccc}
\hline & \multicolumn{2}{c}{ Grasses } & \multicolumn{2}{c}{ Corn Stover } & \multicolumn{2}{c}{ Ag. Residues } & \multicolumn{2}{c}{ Hardwood } \\
\hline Parameter & $\begin{array}{c}\text { Annual } \\
\text { Amount }\end{array}$ & Cost & $\begin{array}{c}\text { Annual } \\
\text { Amount }\end{array}$ & Cost & $\begin{array}{c}\text { Annual } \\
\text { Amount }\end{array}$ & Cost & $\begin{array}{c}\text { Annual } \\
\text { Amount }\end{array}$ & Cost \\
\hline Labor (h) & 84,627 & 5.8 & 83,916 & 5.8 & 84,550 & 5.8 & 77,413 & 5.3 \\
Electricity (MWh) & 91,816 & 9.2 & 94,502 & 9.5 & 115,059 & 11.5 & 123,184 & 12.3 \\
Steam (million t) & 0.9 & 10.9 & 0.8 & 9.1 & 1.4 & 16.5 & 1.9 & 22.5 \\
Cooling water (million t) & 207.2 & 10.4 & 169.0 & 8.5 & 201.1 & 10.1 & 387.2 & 19.4 \\
Chilled water (million t) & 15.5 & 6.2 & 35.2 & 14.1 & 51.9 & 20.8 & 34.6 & 13.8 \\
\hline
\end{tabular}

\subsection{Sensitivity Analysis}

The sugar production cost was highly sensitive to changes in fungal pretreatment time, glucose yield, and bulk density (Figure 6 [87-99]). Variations in the fungal pretreatment time between 7 and 60 days, which are the minimum and maximum values reported in the fungal pretreatment literature used as a data source (Section 2.1.1), produced the greatest change on the sugar production cost for perennial grasses, corn stover, and agricultural residues (Figure 6). Increasing the fungal pretreatment time to 60 days increased the sugar production cost by $42-53 \%$, while reducing it to 7 days decreased it by $33-37 \%$. Decreasing the fungal pretreatment time, while assuming that the process conditions and yields remained unaltered, reduced the numbers of packed-bed bioreactors and the size of the corresponding air compressor, thus reducing the sugar production cost to $1.1,1.0$, and $1.3 \$ / \mathrm{kg}$ for grasses, corn stover, and agricultural residues, respectively.

The glucose and xylose yields varied between the minimum and maximum values reported in the fungal pretreatment literature surveyed for each feedstock (Figure 2). The sugar production cost decreased when the sugar yields increased. Changes in the glucose yield highly influenced the sugar production cost (Figure 6), similarly to previous reports for biological pretreatment [49]. The glucose yield was the most sensitive parameter evaluated for hardwood, and changes in the glucose yield in the range considered caused a $40-45 \%$ variation on the sugar production cost from hardwood (Figure 6D). The glucose yield affected the size of the equipment required, thus affecting the facility-related portion of the cost.

Feedstock bulk density was varied between values reported in literature for each type of feedstock (Figure 6). Assuming a higher bulk density reduced the volume of the equipment needed throughout the facility, hence decreasing the sugar production cost. For example, in the case of chopped agricultural residues, the bulk density of wheat straw has been reported around $50-100 \mathrm{~kg} / \mathrm{m}^{3}$ [62,95], while canola straw has shown a bulk density of around $140-160 \mathrm{~kg} / \mathrm{m}^{3}$ [94]. Assuming the bulk density in the higher range for agricultural residues decreased the sugar production cost by $11 \%$, while assuming the bulk density in the lower range increased the sugar production cost from 2.0 to $3.1 \$ / \mathrm{kg}$ (Figure 6C). The low bulk density of the lignocellulosic feedstocks constituted an important disadvantage for the economics of the process because fungal pretreatment is performed in solid-state. The flowability of biomass in the fungal pretreatment plant could also present difficulties that were not included on this model.

As expected, the cost of materials, such as feedstock and enzymes, or the amount of those materials used for the process, directly affected the sugar production cost. In particular, decreasing the amount of enzymes used for the hydrolysis process from 20 to $5 \mathrm{~g} / \mathrm{kg}$ of cellulose, while assuming that the sugar yields remained unaltered, decreased the sugar production cost by $5-8 \%$ in grasses and corn stover (Figure 6). However, feedstock and enzyme costs were not as sensitive as they have been found with conventional pretreatments $[49,50,65]$, because fungal pretreatment was highly influenced by the high capital cost. 
A

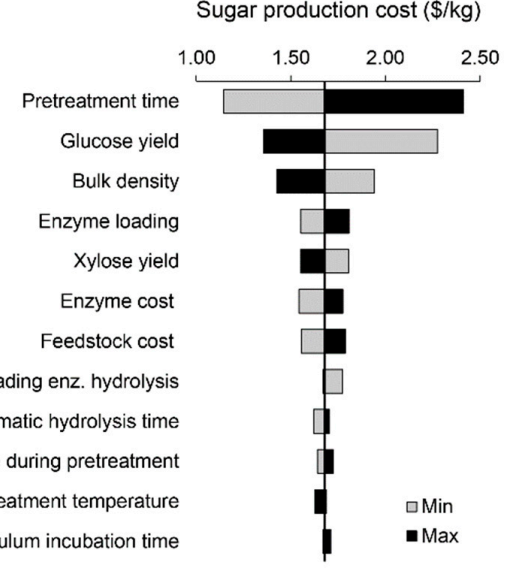

B

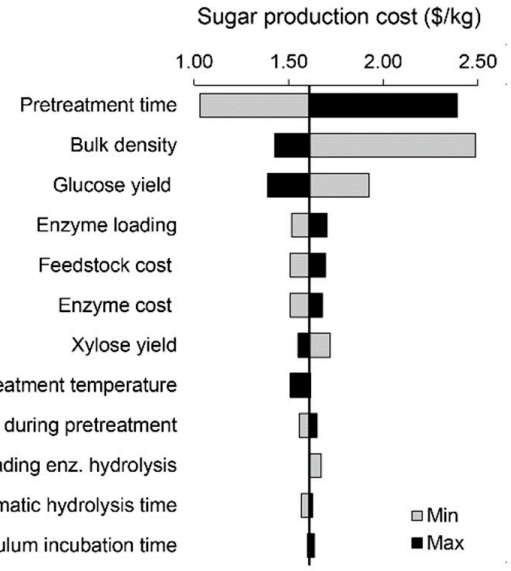

C

Sugar production cost $(\$ / \mathrm{kg})$

$\begin{array}{llllll}00 & 1.50 & 2.00 & 2.50 & 3.00 & 3.50\end{array}$

Pretreatment time

Glucose yield

Bulk density

Xylose yield

Feedstock cost

Pretreatment temperature

Moisture during pretreatment

Enzyme loading

Enzyme cost

Solid loading enz. hydrolysis

Enzymatic hydrolysis time

Inoculum incubation time

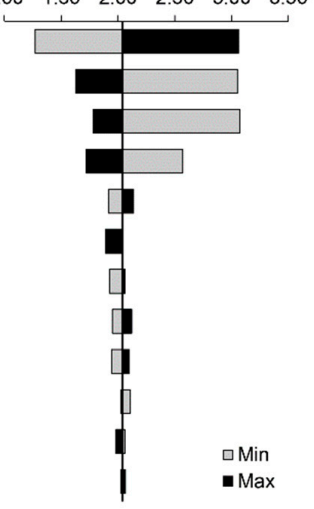

\begin{tabular}{lllll}
\hline Base & Min & Max & Units & Ref. \\
\hline 28 & 7 & 60 & $\mathrm{~d}$ & {$[38]$} \\
58 & 38 & 76 & $\%$ & {$[22,53]$} \\
$215 / 160^{\mathrm{a}}$ & $150 / 120^{\mathrm{a}}$ & $280 / 235^{\mathrm{a}}$ & $\mathrm{kg} / \mathrm{m}^{3}$ & {$[59,60,87]$} \\
20 & 5 & 35 & $\mathrm{~g} / \mathrm{kg}$ cell. & {$[73]$} \\
30 & 21 & 41 & $\%$ & {$[22,53]$} \\
6.5 & 1.25 & 10.14 & $\$ / \mathrm{kg}$ & {$[73]$} \\
97.1 & 65 & 125 & $\$ / \mathrm{t}$ & {$[2]$} \\
20 & 10 & $22.5^{\mathrm{b}}$ & $\%$ & {$[33]$} \\
72 & 16 & 96 & $\mathrm{~h}$ & {$[29,44,45,88]$} \\
75 & 60 & 80 & $\%$ & {$[23,40,53]$} \\
28 & $23^{\mathrm{c}}$ & $50^{\mathrm{d}}$ & ${ }^{\circ} \mathrm{C}$ & \\
120 & 24 & 336 & $\mathrm{~h}$ & {$[33,89]$} \\
\hline
\end{tabular}

\begin{tabular}{lllll}
\hline Base & Min & Max & Units & Ref. \\
\hline 28 & 7 & 60 & $\mathrm{~d}$ & {$[38]$} \\
$220 / 125^{\mathrm{a}}$ & $120 / 60^{\mathrm{a}}$ & $240 / 160^{\mathrm{a}}$ & $\mathrm{kg} / \mathrm{m}^{3}$ & {$[82,90-92]$} \\
61 & 47 & 75 & $\%$ & {$[44,46]$} \\
20 & 5 & 35 & $\mathrm{~g} / \mathrm{kg}$ cell. & {$[73]$} \\
97.4 & 65 & 125 & $\$ / \mathrm{t}$ & {$[2,93]$} \\
6.5 & 1.25 & 10.14 & $\$ / \mathrm{kg}$ & {$[73]$} \\
39 & 31 & 44 & $\%$ & {$[46]$} \\
28 & $23 \mathrm{c}$ & $50^{\mathrm{d}}$ & ${ }^{\circ} \mathrm{C}$ & \\
75 & 60 & 80 & $\%$ & {$[23,40,53]$} \\
20 & 10 & $21^{\mathrm{b}}$ & $\%$ & {$[33]$} \\
72 & 16 & 96 & $\mathrm{~h}$ & {$[29,44,45,88]$} \\
120 & 24 & 336 & $\mathrm{~h}$ & {$[33,89]$} \\
\hline
\end{tabular}

\begin{tabular}{lllll}
\hline Base & Min & Max & Units & Ref. \\
\hline 28 & 7 & 60 & $\mathrm{~d}$ & {$[38]$} \\
51 & 25 & 69 & $\%$ & {$[30,36]$} \\
$180 / 110^{\mathrm{a}}$ & $120 / 55^{\mathrm{a}}$ & $240 / 140^{\mathrm{a}}$ & $\mathrm{kg} / \mathrm{m}^{3}$ & {$[59,94-96]$} \\
39 & 15 & 59 & $\%$ & {$[31,33,38]$} \\
97.4 & 65 & 125 & $\$ / \mathrm{t}$ & {$[2]$} \\
28 & $23^{\mathrm{c}}$ & $50^{\mathrm{d}}$ & ${ }^{\circ} \mathrm{C}$ & \\
75 & 60 & 80 & $\%$ & {$[23,40,53]$} \\
20 & 5 & 35 & $\mathrm{~g} / \mathrm{kg}$ cell. & {$[73]$} \\
6.5 & 1.25 & 10.14 & $\$ / \mathrm{kg}$ & {$[73]$} \\
20 & 10 & $22.4^{\mathrm{b}}$ & $\%$ & {$[33]$} \\
72 & 16 & 96 & $\mathrm{~h}$ & {$[29,44,45,88]$} \\
120 & 24 & 336 & $\mathrm{~h}$ & {$[33,89]$} \\
\hline
\end{tabular}

Figure 6. Cont. 
$\mathrm{D}$

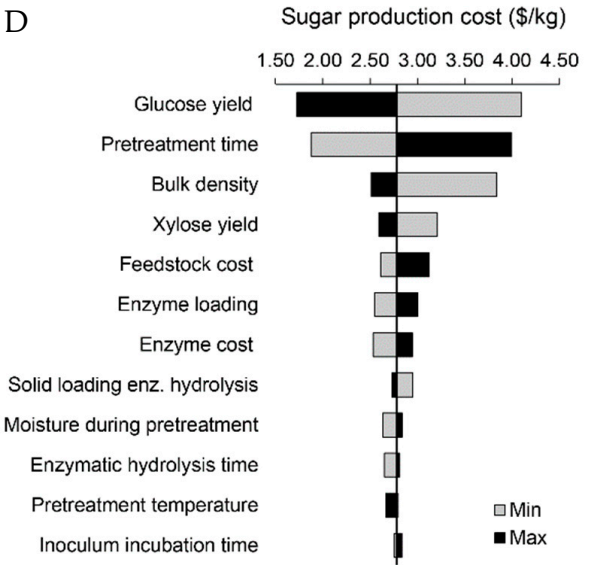

\begin{tabular}{lllll}
\hline Base & Min & Max & Units & Ref. \\
\hline 30 & 17 & 55 & $\%$ & {$[21,22,26]$} \\
28 & 7 & 60 & $\mathrm{~d}$ & {$[38]$} \\
320 & 180 & 400 & $\mathrm{~kg} / \mathrm{m}^{3}$ & {$[57,97]$} \\
23 & 11 & 29 & $\%$ & {$[22,23]$} \\
76.3 & 53 & 125 & $\$ / \mathrm{t}$ & {$[63,98,99]$} \\
20 & 5 & 35 & $\mathrm{~g} / \mathrm{kg}$ cell. & {$[73]$} \\
6.5 & 1.25 & 10.14 & $\$ / \mathrm{kg}$ & {$[73]$} \\
20 & 10 & $27.8^{\mathrm{b}}$ & $\%$ & {$[33]$} \\
75 & 60 & 80 & $\%$ & {$[23,40,53]$} \\
72 & 16 & 96 & $\mathrm{~h}$ & {$[29,44,45,88]$} \\
28 & $23^{\mathrm{c}}$ & $50^{\mathrm{d}}$ & ${ }^{\circ} \mathrm{C}$ & \\
120 & 24 & 336 & $\mathrm{~h}$ & {$[33,89]$} \\
\hline
\end{tabular}

Figure 6. Sensitivity analysis of the fungal pretreatment-based facility for the production of fermentable sugars from: (A) perennial grasses, (B) corn stover, (C) agricultural residues, and (D) hardwood. ${ }^{\text {a Bulk }}$ density of baled and chopped biomass, respectively. ${ }^{b}$ Achieved by eliminating water addition to the enzymatic hydrolysis process. ${ }^{c}$ Room temperature. ${ }^{d}$ Same temperature as enzymatic hydrolysis, assuming use of fungi that would withstand that temperature.

The assumed $20 \%$ solid loading for the enzymatic hydrolysis process is considered a high-solid loading. High-solid loadings are preferred for enzymatic hydrolysis and are usually beneficial for the process economics, but can produce challenges related to the rheology of the mixture [100]. Most experimental results in enzymatic hydrolysis are obtained using very low solid loading of $1-5 \%$, including the values from literature used as a data source in this model (Table S1) [21-46,51-53]. However, for the purpose of this analysis, it was assumed that similar yields to those reported would be obtained at $20 \%$ solid loadings. Reducing the solid loading to $10 \%$, while maintaining the sugar yields, increased the sugar production cost for all feedstocks by $4-5 \%$. However, reducing the solid loading could generate an increase on the sugar yields, which was not accounted for in this study. The maximum solid loading possible for enzymatic hydrolysis corresponded to the final solid loading of the fungal pretreatment, and to model this scenario, no additional water was added with the enzymes to the enzymatic hydrolysis process. The actual maximum solid loading varied between feedstocks (Figure 6), because some of the reactions during the fungal pretreatment process produced water, such as the lignin mineralization and the sugar metabolization and, therefore, the actual moisture content at the end of the fungal pretreatment was different for each feedstock.

The low temperature used for fungal pretreatment $\left(25-30^{\circ} \mathrm{C}\right)$ has been considered an advantage because of low energy requirements [17]. However, these results showed that the fungal pretreatment process at this scale (Table A2) actually required cooling water due to the heat produced by the fungal metabolism (Table 4). In addition, an important amount of water was required to decrease the temperature of the sterilized feedstock. Therefore, increasing the fungal pretreatment temperature to that of the enzymatic hydrolysis $\left(50{ }^{\circ} \mathrm{C}\right)$ reduced the sugar production cost by $4-6 \%$, by reducing the demand for cooling water.

Fungal pretreatment has been performed successfully at $60 \%$ initial moisture content [101]. Reducing the initial moisture content for the fungal pretreatment to that level decreased the sugar production cost by $4-6 \%$ (Figure 6), mostly because service water was saved in the cool down process after autoclaving of the feedstocks with $60 \%$ moisture content, since water has a high specific heating capacity. The time required for operations such as inoculum preparation or enzymatic hydrolysis were reduced to 24 and 16 hours, respectively, which are levels already reported in the literature $[33,46]$. This time reduction decreased the equipment needs for those processes and, thus, reduced the sugar production cost by $2-5 \%$. 


\subsection{Potential Strategies to Reduce the Sugar Production Cost}

To study the effect of some potential strategies to reduce the sugar production cost, the model for corn stover was selected as baseline, since it produced the lowest sugar production cost (Figure 4). Feedstock sterilization was reportedly performed on all the experiments used as a data source for the fungal pretreatment conditions and yields (Section 2.1.1) and, therefore, was included in the baseline process models. Some recent research interest has been focused on reducing the sterilization requirements of the fungal pretreatment $[39,102,103]$; however, the results have shown significant limitations of this approach [53]. If eliminating the sterilization step was possible, the estimated sugar production cost in the fungal pretreatment-based facility from corn stover would be around $\$ 1.4 / \mathrm{kg}$ (Figure 7). Furthermore, by reducing the fungal pretreatment time to 7 days, the sugar production cost could be decreased to $\$ 0.9 / \mathrm{kg}$ (Figure 7). However, this short pretreatment time would unlikely produce sufficient changes in the recalcitrance of the feedstocks to maintain the required sugar yields [17], and improvements on the fungal strains would be necessary to make this time reduction feasible.

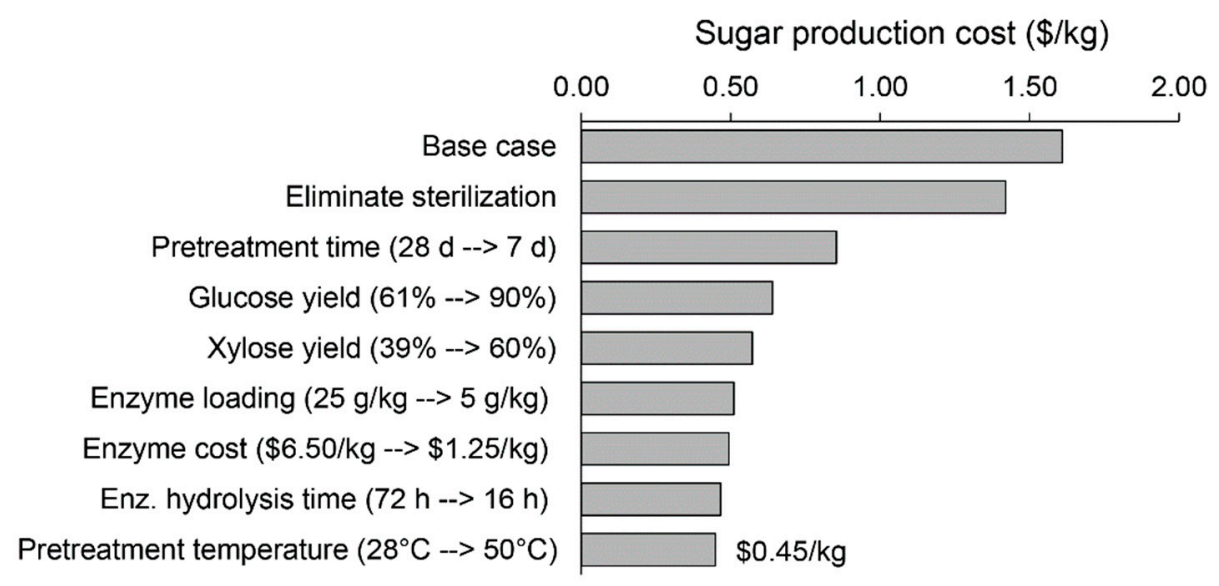

Figure 7. Potential strategies for the reduction of fermentable sugar production cost in a fungal pretreatment-based facility from corn stover.

It has been reported that, to make a pretreatment economically feasible, a glucose yield of at least $90 \%$ should be achieved [4]. If that were possible for fungal pretreatment in this process model, the sugar production cost would be further reduced to approximately $\$ 0.6 / \mathrm{kg}$ (Figure 7). An increase of the xylose yield to levels previously reported for other feedstocks was also considered [33]. Other considerations evaluated in the sensitivity analysis were also included to reduce the sugar production cost, such as reducing the enzyme loading cost and enzymatic hydrolysis time, and increasing the pretreatment temperature to $50^{\circ} \mathrm{C}$. The latter assumed that a white-rot fungus is selected or modified to be effective at that temperature. By combining these strategies, an estimated cost of $\$ 0.45 / \mathrm{kg}$ of fermentable sugars could potentially be achieved (Figure 7). Previous reports have estimated a cost of approximately $\$ 0.25 / \mathrm{kg}$ of fermentable sugars for cellulosic biorefineries [49,50].

In the sensitivity analysis, it was shown that decreasing the initial moisture content of the fungal pretreatment considerably decreased the sugar production cost. However, this was mostly due to cooling water saved after the sterilization process. Since sterilization was eliminated in the analysis performed in Figure 7, the reduction of the initial moisture content had only a slight effect on the sugar production cost and was, therefore, not included in this analysis.

Feedstock sterilization is usually considered as an important step prior to fungal pretreatment, to avoid the outcompetition of the white-rot fungi by microorganisms present in the feedstock [104]. However, the amount of energy required for sterilization by autoclaving could be detrimental to the process economics of the fungal pretreatment. Alternative methods of sterilization, such as gamma radiation or ethylene oxide, could be more appropriate for lignocellulosic feedstock at this scale, but 
need to be explored experimentally. Eliminating feedstock sterilization reduced the sugar production cost by approximately $12 \%$ in the fungal pretreatment-based facility analyzed (Figure 7 ). In addition, elimination of the sterilization requirement would allow the fungal pretreatment process to take place in less enclosed environments. Fungal pretreatment in piles, similar to composting, instead of packed-bed bioreactors would notably reduce the costs. Fungal pretreatment concurrent with wet storage has been proposed previously for the scale up of this process [88], and the elimination of the feedstock sterilization would benefit the feasibility of this approach. However, it is not clear if the complete elimination of sterilization is feasible. Fungi with high growth rates and/or mechanisms that allow them to outcolonize the microorganisms present in the feedstock would be required to eliminate the sterilization process. An incomplete microbial reduction, instead of sterilization, could perhaps create an environment that would allow the white-rot fungi to properly colonize the feedstock and to perform an effective fungal pretreatment.

In order to improve the fungal pretreatment process towards feasibility at commercial scale, several bottlenecks need to be overcome. Reducing the fungal pretreatment time and increasing the sugar yields constitute some of the biggest challenges. To increase the sugar yields and reduce the pretreatment time, more advanced strategies for the optimization of the fungal pretreatment are necessary. Combination with other low severity pretreatments has been studied for a long time, achieving high sugar yields and significantly reducing energy and chemical inputs [105]. These processes should be optimized not only from the technical perspective at laboratory scale, but also from the techno-economic perspective for commercial scale application. Genetic modifications of fungal strains in order to improve lignin degradation, restrict carbohydrates loss, raise the growth rate, or increase the optimal growth temperature have the potential to improve the fungal pretreatment process in the future. White-rot fungi have been modified for overexpression of ligninolytic enzymes [106], heterologous expression of lignocellulases [107,108], and avoidance of cellulase production to restrict cellulose loss [32]. Developing new microbial strains that exploit the ligninolytic systems of white-rot fungi, while including benefits of different microorganisms, such as the higher growth rate of bacteria or yeast, could help develop a better platform for the optimization of biological pretreatment.

\section{Conclusions}

The production of fermentable sugars for a cellulosic biorefinery producing $75,700 \mathrm{~m}^{3}$ of ethanol per year (20 million gallons per year) in a fungal pretreatment-based facility does not appear to be economically feasible at the conditions evaluated. The sugar production costs estimated in this analysis were $1.7,1.6,2.0$, and $2.8 \$ / \mathrm{kg}$ for perennial grasses, corn stover, agricultural residues other than corn stover, and hardwood, respectively. These values were 4-15 times as much as those obtained previously for conventional pretreatments. The main bottlenecks of the fungal pretreatment process were the long pretreatment time, the low sugar yields, the low feedstock bulk density, and the sterilization requirements. These conditions generated high requirements in equipment size and number of units for key processes, such as fungal pretreatment, enzymatic hydrolysis, and autoclaving, which had a direct impact on the capital cost and, thus, the fermentable sugars production cost. In a hypothetical optimization of the fungal pretreatment process, by eliminating the sterilization step, reducing the pretreatment time from 28 to 7 days, and increasing the glucose yield to $90 \%$, the sugar production cost from corn stover could be potentially reduced by more than $60 \%$, to $\$ 0.6 / \mathrm{kg}$. Thus, the improvement of key parameters, such as sugar yield, pretreatment time and sterilization requirements, are necessary to improve the techno-economic performance of the fungal pretreatment of lignocellulosic biomass.

Supplementary Materials: The following are available online at http://www.mdpi.com/2311-5637/5/2/30/s1. Table S1: Summary of data from fungal pretreatment literature, Table S2: Cost of utilities used for model, Table S3: Direct fixed capital estimate summary (million dollars). 
Author Contributions: Conceptualization, A.S. and J.V.-C.; methodology, J.V.-C.; validation, J.V.-C. and A.S.; formal analysis, J.V.-C.; investigation, J.V.-C.; resources, A.S.; data curation, J.V.-C.; writing-original draft preparation, J.V.-C.; writing-review and editing, A.S.; visualization, J.V.-C.; supervision, A.S.; project administration, A.S. and J.V.-C.; funding acquisition, A.S. and J.V.-C.

Funding: This research was funded by the Schlumberger Foundation Faculty of the Future Program awarded to support postdoctoral research of J.V.-C, and USDA NIFA Hatch project (1005665).

Conflicts of Interest: The authors declare no conflict of interest. The funders had no role in the design of the study; in the collection, analyses, or interpretation of data; in the writing of the manuscript, or in the decision to publish the results.

\section{Appendix A}

Table A1. Economic evaluation parameters.

\begin{tabular}{|c|c|c|c|c|c|}
\hline Time Parameters & Value & Financing Parameters & Value & Construction Plan & Value \\
\hline Analysis year & 2017 & Equity (\%) & 40 & 1st year (\% of DFC) & 30 \\
\hline Year construction starts & 2017 & Loan term (years) & 12 & 2nd year (\% of DFC) & 40 \\
\hline $\begin{array}{l}\text { Construction period } \\
\text { (months) }\end{array}$ & 18 & Loan interest (\%) & 8 & 3rd year ( $\%$ of DFC) & 30 \\
\hline Startup period (months) & 12 & Depreciation method & Straight line & Plant direct cost parameters: & \\
\hline Project life (years) & 30 & $\begin{array}{l}\text { Depreciation period } \\
\text { (years) }\end{array}$ & 15 & Process piping (\% of PC) & 35 \\
\hline Inflation rate $(\%)$ & 2 & Income tax rate $(\%)$ & 40 & Instrumentation (\% of PC) & 40 \\
\hline Fixed cost parameters: & & Operating parameters: & & Insulation (\% of PC) & 5 \\
\hline Auxiliary facilities (\% of PC) & 40 & Annual operating time (h) & 7920 & Electrical (\% of PC) & 10 \\
\hline Engineering ( $\%$ of TPDC) & 20 & Salvage factor (\% of DFC) & 5 & Buildings ( $\%$ of PC) & 45 \\
\hline Construction (\% of TPDC) & 20 & Startup cost (\% of DFC) & 5 & Yard improvement (\% of PC) & 15 \\
\hline Contractor's fee (\% of TPC) & 5 & & & & \\
\hline Contingency (\% of TPC) & 10 & & & & \\
\hline
\end{tabular}

Based on: [49,50,77-79]. PC: purchase cost of equipment; TPDC: total plant direct cost (physical cost); TPC: total plant cost (includes TPDC and indirect cost,); DFC: direct fixed capital.

Table A2. Major equipment characteristics, number, size, and cost.

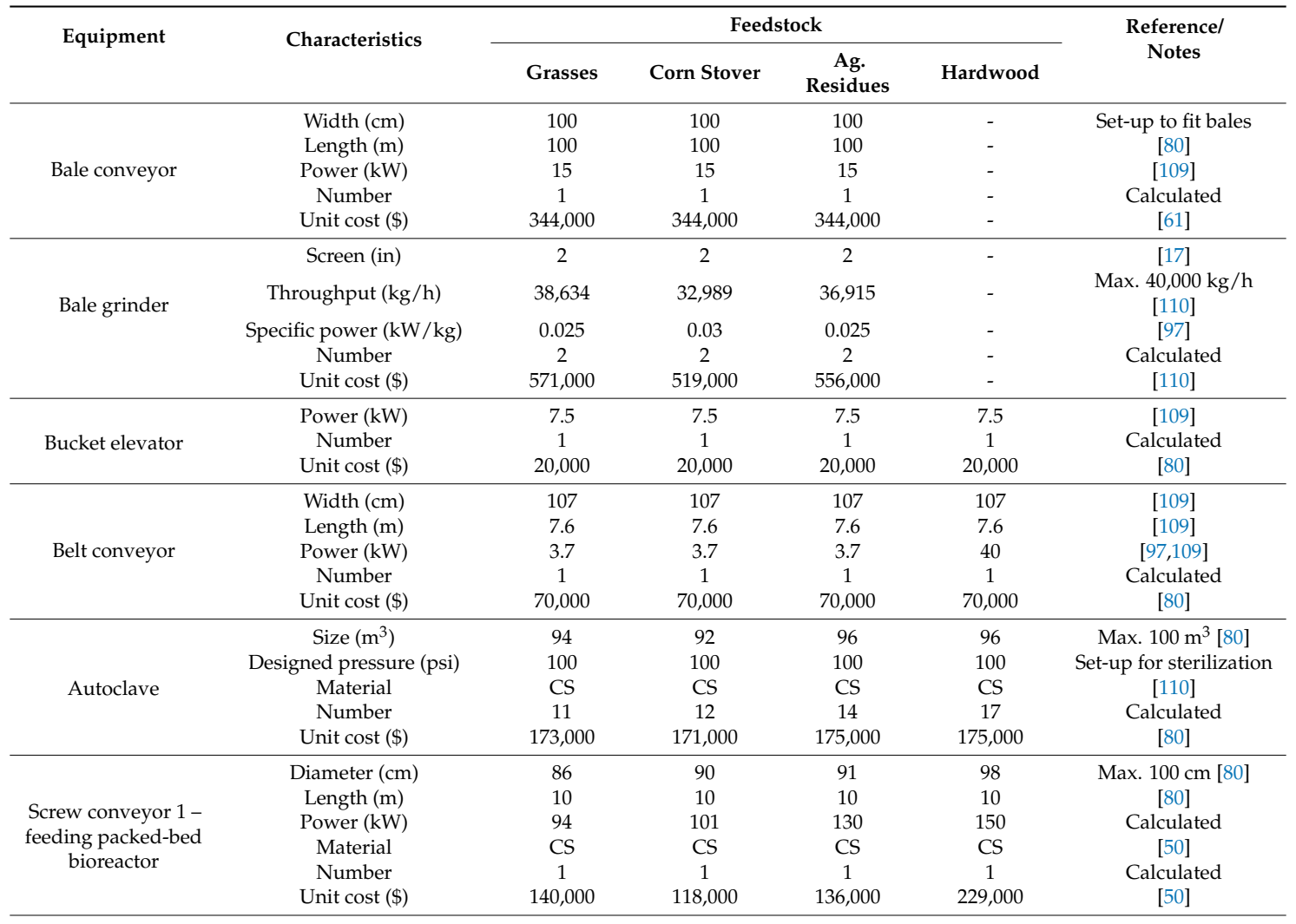


Table A2. Cont.

\begin{tabular}{|c|c|c|c|c|c|c|}
\hline \multirow{2}{*}{ Equipment } & \multirow{2}{*}{ Characteristics } & \multicolumn{4}{|c|}{ Feedstock } & \multirow{2}{*}{$\begin{array}{l}\text { Reference/ } \\
\text { Notes }\end{array}$} \\
\hline & & Grasses & Corn Stover & $\begin{array}{c}\text { Ag. } \\
\text { Residues }\end{array}$ & Hardwood & \\
\hline \multirow{4}{*}{$\begin{array}{l}\text { Airlift fermenter } \\
\text { (inoculum } \\
\text { preparation } \\
\text { bioreactor) }\end{array}$} & Size $\left(\mathrm{m}^{3}\right)$ & 980 & 787 & 936 & 900 & \multirow{4}{*}{$\begin{array}{l}\text { Calculated } \\
\text { [80] } \\
\text { Calculated } \\
{[80]}\end{array}$} \\
\hline & Material & SS316 & SS316 & SS316 & SS316 & \\
\hline & Number & 1 & 1 & 1 & 2 & \\
\hline & Unit cost (\$) & $1,208,000$ & $1,054,000$ & $1,174,000$ & $1,146,000$ & \\
\hline \multirow{5}{*}{$\begin{array}{l}\text { Gas compressor for } \\
\text { inoculum } \\
\text { preparation }\end{array}$} & Pressure change (psi) & 16 & 16 & 16 & 16 & \multirow{5}{*}{$\begin{array}{c}{[50]} \\
{[80]} \\
\text { Calculated } \\
\text { Calculated } \\
{[50]}\end{array}$} \\
\hline & Efficiency $(\%)$ & 70 & 70 & 70 & 70 & \\
\hline & Power $(\mathrm{kW})$ & 646 & 519 & 617 & 1188 & \\
\hline & Number & 1 & 1 & 1 & 1 & \\
\hline & Unit cost $(\$)$ & 257,000 & 225,000 & 250,000 & 370,000 & \\
\hline \multirow{4}{*}{$\begin{array}{l}\text { Packed-bed } \\
\text { bioreactor (fungal } \\
\text { pretreatment) }\end{array}$} & Size $\left(\mathrm{m}^{3}\right)$ & 3999 & 3972 & 3974 & 3976 & \multirow{4}{*}{$\begin{array}{c}\text { Max. } 4000 \mathrm{~m}^{3} \\
{[50]} \\
\text { Calculated } \\
{[50]}\end{array}$} \\
\hline & Material & Concrete & Concrete & Concrete & Concrete & \\
\hline & Number & 85 & 92 & 120 & 142 & \\
\hline & Unit cost (\$) & 986,000 & 983,000 & 983,000 & 983,000 & \\
\hline \multirow{5}{*}{$\begin{array}{l}\text { Gas compressor for } \\
\text { fungal pretreatment }\end{array}$} & Pressure change (psi) & 16 & 16 & 16 & 16 & \multirow{5}{*}{$\begin{array}{c}\quad[50] \\
{[80]} \\
\text { Calculated } \\
\text { Calculated } \\
{[50]}\end{array}$} \\
\hline & Efficiency $(\%)$ & 70 & 70 & 70 & 70 & \\
\hline & Power (kW) & 6000 & 6450 & 4208 & 4957 & \\
\hline & Number & 1 & 1 & 2 & 2 & \\
\hline & Unit cost $(\$)$ & 978,000 & $1,022,000$ & 791,000 & 872,000 & \\
\hline \multirow{6}{*}{$\begin{array}{l}\text { Screw conveyor } 2- \\
\text { feeding enzymatic } \\
\text { hydrolysis reactor }\end{array}$} & Diameter (cm) & 78 & 80 & 91 & 92 & \multirow{6}{*}{$\begin{array}{c}{[80]} \\
{[80]} \\
\text { Calculated } \\
{[80]} \\
\text { Calculated } \\
{[50]}\end{array}$} \\
\hline & Length (m) & 15 & 15 & 15 & 15 & \\
\hline & Power $(\mathrm{kW})$ & 115 & 119 & 156 & 197 & \\
\hline & Material & CS & CS & CS & CS & \\
\hline & Number & 1 & 1 & 1 & 1 & \\
\hline & Unit cost (\$) & 165,000 & 138,000 & 157,000 & 270,000 & \\
\hline \multirow{4}{*}{$\begin{array}{c}\text { Enzymatic } \\
\text { hydrolysis reactor }\end{array}$} & Size $\left(\mathrm{m}^{3}\right)$ & 2300 & 2321 & 2333 & 2482 & \multirow{4}{*}{$\begin{array}{c}\text { Max. } 2500 \mathrm{~m}^{3}[50] \\
{[50]} \\
\text { Calculated } \\
{[50]}\end{array}$} \\
\hline & Material & SS304 & SS304 & SS304 & SS304 & \\
\hline & Number & 11 & 8 & 10 & 22 & \\
\hline & Unit cost (\$) & 958,000 & 963,000 & 966,000 & $1,003,000$ & \\
\hline
\end{tabular}

Materials: CS - Carbon steel, SS304 - Stainless steel grade 304, SS316 - Stainless steel grade 316 . Costs were calculated using the power law based using the references provided in the last column as based price.

Table A3. Annual operating costs for the fungal pretreatment-based facility for the production of fermentable sugars from different feedstocks (million dollars).

\begin{tabular}{ccccc}
\hline Cost Item & Grasses & Corn Stover & Ag. Residues & Hardwood \\
\hline Feedstock & 50.5 & 40.7 & 48.4 & 72.9 \\
Enzymes & 22.9 & 16.8 & 15.2 & 40.7 \\
Other materials & 5.5 & 4.4 & 5.3 & 10.3 \\
Labor & 5.9 & 5.8 & 5.8 & 5.3 \\
Facility-dependent & 104.2 & 108.0 & 139.8 & 175.8 \\
Laboratory/QC/QA & 0.9 & 0.9 & 0.9 & 0.9 \\
Utilities & 36.7 & 41.1 & 58.9 & 68.0 \\
\hline TOTAL & $\mathbf{2 2 6 . 6}$ & $\mathbf{2 1 7 . 6}$ & $\mathbf{2 7 4 . 2}$ & $\mathbf{3 7 3 . 8}$ \\
\hline
\end{tabular}


Table A4. Cost of major equipment for fungal pretreatment-based facility (thousand dollars).

\begin{tabular}{|c|c|c|c|c|c|c|c|c|}
\hline \multirow[b]{2}{*}{ Equipment } & \multicolumn{2}{|c|}{ Grasses } & \multicolumn{2}{|c|}{ Corn Stover } & \multicolumn{2}{|c|}{ Ag. Residues } & \multicolumn{2}{|c|}{ Hardwood } \\
\hline & Quantity & $\begin{array}{l}\text { Total } \\
\text { Cost }\end{array}$ & Quantity & $\begin{array}{l}\text { Total } \\
\text { Cost }\end{array}$ & Quantity & $\begin{array}{l}\text { Total } \\
\text { Cost }\end{array}$ & Quantity & $\begin{array}{l}\text { Total } \\
\text { Cost }\end{array}$ \\
\hline Packed-bed bioreactor & 85 & 83,810 & 92 & 90,436 & 120 & 117,960 & 142 & 139,586 \\
\hline $\begin{array}{l}\text { Enzymatic hydrolysis } \\
\text { reactor }\end{array}$ & 11 & 10,538 & 8 & 7704 & 10 & 9660 & 22 & 22,066 \\
\hline Autoclave & 11 & 1903 & 12 & 2052 & 14 & 2450 & 17 & 2975 \\
\hline Airlift fermenter & 1 & 1208 & 1 & 1054 & 1 & 1174 & 2 & 2292 \\
\hline Hammer mill & 2 & 1142 & 2 & 1036 & 2 & 1112 & - & - \\
\hline $\begin{array}{c}\text { Gas compressor for fungal } \\
\text { pretreatment }\end{array}$ & 1 & 978 & 1 & 1022 & 2 & 1582 & 2 & 1744 \\
\hline Bale conveyor & 1 & 344 & 1 & 344 & 1 & 344 & - & - \\
\hline $\begin{array}{l}\text { Gas compressor for } \\
\text { inoculum }\end{array}$ & 1 & 257 & 1 & 225 & 1 & 250 & 1 & 370 \\
\hline Screw conveyor 1 & 1 & 140 & 1 & 118 & 1 & 136 & 1 & 229 \\
\hline Screw conveyor 2 & 1 & 165 & 1 & 138 & 1 & 157 & 1 & 270 \\
\hline Belt conveyor & 1 & 70 & 1 & 70 & 1 & 70 & 1 & 70 \\
\hline Bucket elevator & 1 & 20 & 1 & 20 & 1 & 20 & 1 & 20 \\
\hline Other equipment & - & 25,181 & - & 26,080 & - & 33,762 & - & 42,469 \\
\hline TOTAL & & 125,756 & & 130,299 & & 168,677 & & 212,091 \\
\hline
\end{tabular}

\section{References}

1. Cherubini, F. The biorefinery concept: Using biomass instead of oil for producing energy and chemicals. Energy Convers. Manag. 2010, 51, 1412-1421. [CrossRef]

2. U.S. Department of Energy. 2016 Billion-Ton Report: Advancing Domestic Resources for a Thriving Bioeconomy, Volume 1: Economic Availability of Feedstocks; U.S. Department of Energy: Oak Ridge, TN, USA, 2016.

3. Williams, C.L.; Westover, T.L.; Emerson, R.M.; Tumuluru, J.S.; Li, C. Sources of biomass feedstock variability and the potential impact on biofuels production. BioEnergy Res. 2016, 9, 1-14. [CrossRef]

4. Yang, B.; Wyman, C.E. Pretreatment: The key to unlocking low-cost cellulosic ethanol. Biofuels Bioprod. Biorefin. 2008, 2, 26-40. [CrossRef]

5. Mosier, N.S.; Wyman, C.E.; Dale, B.E.; Elander, R.T.; Lee, Y.Y.; Holtzapple, M.; Ladisch, M.R. Features of promising technologies for pretreatment of lignocellulosic biomass. Bioresour. Technol. 2005, 96, 673-686. [CrossRef] [PubMed]

6. Baral, N.R.; Shah, A. Microbial inhibitors: Formation and effects on acetone-butanol-ethanol fermentation of lignocellulosic biomass. Appl. Microbiol. Biotechnol. 2014, 98, 9151-9172. [CrossRef]

7. Hassan, S.S.; Williams, G.A.; Jaiswal, A.K. Emerging technologies for the pretreatment of lignocellulosic biomass. Bioresour. Technol. 2018, 262, 310-318. [CrossRef]

8. Li, M.-F.; Yang, S.; Sun, R.-C. Recent advances in alcohol and organic acid fractionation of lignocellulosic biomass. Bioresour. Technol. 2016, 200, 971-980. [CrossRef] [PubMed]

9. Zhang, K.; Pei, Z.; Wang, D. Organic solvent pretreatment of lignocellulosic biomass for biofuels and biochemicals: A review. Bioresour. Technol. 2016, 199, 21-33. [CrossRef] [PubMed]

10. Travaini, R.; Martín-Juárez, J.; Lorenzo-Hernando, A.; Bolado-Rodríguez, S. Ozonolysis: An advantageous pretreatment for lignocellulosic biomass revisited. Bioresour. Technol. 2016, 199, 2-12. [CrossRef] [PubMed]

11. Grilc, M.; Likozar, B.; Levec, J. Kinetic model of homogeneous lignocellulosic biomass solvolysis in glycerol and imidazolium-based ionic liquids with subsequent heterogeneous hydrodeoxygenation over NiMo/Al2O3 catalyst. Catal. Today 2015, 256, 302-314. [CrossRef]

12. Elgharbawy, A.A.; Alam, M.Z.; Moniruzzaman, M.; Goto, M. Ionic liquid pretreatment as emerging approaches for enhanced enzymatic hydrolysis of lignocellulosic biomass. Biochem. Eng. J. 2016, 109, $252-267$. [CrossRef]

13. Mamilla, J.L.K.; Novak, U.; Grilc, M.; Likozar, B. Natural deep eutectic solvents (DES) for fractionation of waste lignocellulosic biomass and its cascade conversion to value-added bio-based chemicals. Biomass Bioenergy 2019, 120, 417-425. [CrossRef]

14. Kumar, A.K.; Sharma, S. Recent updates on different methods of pretreatment of lignocellulosic feedstocks: A review. Bioresour. Bioprocess. 2017, 4, 7. [CrossRef] 
15. van Osch, D.J.G.P.; Kollau, L.J.B.M.; van den Bruinhorst, A.; Asikainen, S.; Rocha, M.A.A.; Kroon, M.C. Ionic liquids and deep eutectic solvents for lignocellulosic biomass fractionation. Phys. Chem. Chem. Phys. 2017, 19, 2636-2665. [CrossRef]

16. Baral, N.R.; Shah, A. Techno-economic analysis of cellulose dissolving ionic liquid pretreatment of lignocellulosic biomass for fermentable sugars production. Biofuels Bioprod. Biorefin. 2016, 10, 70-88. [CrossRef]

17. Wan, C.; Li, Y. Fungal pretreatment of lignocellulosic biomass. Biotechnol. Adv. 2012, 30, 1447-1457. [CrossRef]

18. Vasco-Correa, J.; Ge, X.; Li, Y. Biological pretreatment of lignocellulosic biomass. In Biomass Fractionation Technologies for a Lignocellulosic Feedstock Based Biorefinery; Mussatto, S.I., Ed.; Elsevier: Amsterdam, The Netherlands, 2016; pp. 561-586. ISBN 9780128023235.

19. Singh, A.P.; Singh, T. Biotechnological applications of wood-rotting fungi: A review. Biomass Bioenergy 2014, 62, 198-206. [CrossRef]

20. Saritha, M.; Arora, A.; Lata. Biological pretreatment of lignocellulosic substrates for enhanced delignification and enzymatic digestibility. Indian J. Microbiol. 2012, 52, 122-130. [CrossRef]

21. Nazarpour, F.; Abdullah, D.K.; Abdullah, N.; Zamiri, R. Evaluation of biological pretreatment of rubberwood with white rot fungi for enzymatic hydrolysis. Materials (Basel). 2013, 6, 2059-2073. [CrossRef]

22. Wan, C.; Li, Y. Effectiveness of microbial pretreatment by Ceriporiopsis subvermispora on different biomass feedstocks. Bioresour. Technol. 2011, 102, 7507-7512. [CrossRef]

23. Ge, X.; Matsumoto, T.; Keith, L.; Li, Y. Fungal pretreatment of albizia chips for enhanced biogas production by solid-state anaerobic digestion. Energy Fuels 2015, 29, 200-204. [CrossRef]

24. Wang, W.; Yuan, T.; Cui, B. Biological pretreatment with white rot fungi and their co-culture to overcome lignocellulosic recalcitrance for improved enzymatic digestion. BioResources 2014, 9, 3968-3976. [CrossRef]

25. Wang, W.; Yuan, T.; Cui, B.; Dai, Y. Pretreatment of Populus tomentosa with Trametes velutina supplemented with inorganic salts enhances enzymatic hydrolysis for ethanol production. Biotechnol. Lett. 2012, 34, 2241-2246. [CrossRef] [PubMed]

26. Yu, H.; Guo, G.; Zhang, X.; Yan, K.; Xu, C. The effect of biological pretreatment with the selective white-rot fungus Echinodontium taxodii on enzymatic hydrolysis of softwoods and hardwoods. Bioresour. Technol. 2009, 100, 5170-5175. [CrossRef] [PubMed]

27. López-Abelairas, M.; Álvarez Pallín, M.; Salvachúa, D.; Lú-Chau, T.; Martínez, M.J.; Lema, J.M. Optimisation of the biological pretreatment of wheat straw with white-rot fungi for ethanol production. Bioprocess. Biosyst. Eng. 2013, 36, 1251-1260. [CrossRef] [PubMed]

28. Singh, D.; Zeng, J.; Laskar, D.D.; Deobald, L.; Hiscox, W.C.; Chen, S. Investigation of wheat straw biodegradation by Phanerochaete chrysosporium. Biomass Bioenergy 2011, 35, 1030-1040. [CrossRef]

29. Zhi, Z.; Wang, H. White-rot fungal pretreatment of wheat straw with Phanerochaete chrysosporium for biohydrogen production: Simultaneous saccharification and fermentation. Bioprocess. Biosyst. Eng. 2014, 37, 1447-1458. [CrossRef] [PubMed]

30. Salvachúa, D.; Prieto, A.; López-Abelairas, M.; Lu-Chau, T.; Martínez, A.T.; Martínez, M.J. Fungal pretreatment: An alternative in second-generation ethanol from wheat straw. Bioresour. Technol. 2011, 102, 7500-7506. [CrossRef]

31. Saritha, M.; Arora, A.; Nain, L. Pretreatment of paddy straw with Trametes hirsuta for improved enzymatic saccharification. Bioresour. Technol. 2012, 104, 459-465. [CrossRef]

32. Canam, T.; Town, J.R.; Tsang, A.; McAllister, T.A.; Dumonceaux, T.J. Biological pretreatment with a cellobiose dehydrogenase-deficient strain of Trametes versicolor enhances the biofuel potential of canola straw. Bioresour. Technol. 2011, 102, 10020-10027. [CrossRef]

33. García-Torreiro, M.; López-Abelairas, M.; Lu-Chau, T.A.; Lema, J.M. Fungal pretreatment of agricultural residues for bioethanol production. Ind. Crops Prod. 2016, 89, 486-492. [CrossRef]

34. Taniguchi, M.; Suzuki, H.; Watanabe, D.; Sakai, K.; Hoshino, K.; Tanaka, T. Evaluation of pretreatment with Pleurotus ostreatus for enzymatic hydrolysis of rice straw. J. Biosci. Bioeng. 2005, 100, 637-643. [CrossRef] [PubMed]

35. Bak, J.S.; Kim, M.D.; Choi, I.G.; Kim, K.H. Biological pretreatment of rice straw by fermenting with Dichomitus squalens. N. Biotechnol. 2010, 27, 424-434. [CrossRef]

36. Cianchetta, S.; Di Maggio, B.; Burzi, P.L.; Galletti, S. Evaluation of selected white-rot fungal isolates for improving the sugar yield from wheat straw. Appl. Biochem. Biotechnol. 2014, 173, 609-623. [CrossRef] 
37. Mishra, V.; Jana, A.K. Fungal pretreatment of sweet sorghum bagasse with combined $\mathrm{CuSO}_{4}$-gallic acid supplement for improvement in lignin degradation, selectivity, and enzymatic saccharification. Appl. Biochem. Biotechnol. 2017, 183, 200-217. [CrossRef] [PubMed]

38. Machado, A.D.S.; Ferraz, A. Biological pretreatment of sugarcane bagasse with basidiomycetes producing varied patterns of biodegradation. Bioresour. Technol. 2017, 225, 17-22. [CrossRef]

39. Vasco-Correa, J.; Ge, X.; Li, Y. Fungal pretreatment of non-sterile miscanthus for enhanced enzymatic hydrolysis. Bioresour. Technol. 2016, 203, 118-123. [CrossRef]

40. Liu, J.; Wang, M.L.; Tonnis, B.; Habteselassie, M.; Liao, X.; Huang, Q. Fungal pretreatment of switchgrass for improved saccharification and simultaneous enzyme production. Bioresour. Technol. 2013, 135, 39-45. [CrossRef] [PubMed]

41. Wan, C.; Li, Y. Microbial delignification of corn stover by Ceriporiopsis subvermispora for improving cellulose digestibility. Enzyme Microb. Technol. 2010, 47, 31-36. [CrossRef]

42. Wan, C.; Li, Y. Microbial pretreatment of corn stover with Ceriporiopsis subvermispora for enzymatic hydrolysis and ethanol production. Bioresour. Technol. 2010, 101, 6398-6403. [CrossRef]

43. Song, L.; Ma, F.; Zeng, Y.; Zhang, X.; Yu, H. The promoting effects of manganese on biological pretreatment with Irpex lacteus and enzymatic hydrolysis of corn stover. Bioresour. Technol. 2013, 135, 89-92. [CrossRef]

44. Zhao, L.; Cao, G.-L.; Wang, A.-J.; Ren, H.-Y.; Dong, D.; Liu, Z.-N.; Guan, X.-Y.; Xu, C.-J.; Ren, N.-Q. Fungal pretreatment of cornstalk with Phanerochaete chrysosporium for enhancing enzymatic saccharification and hydrogen production. Bioresour. Technol. 2012, 114, 365-369. [CrossRef]

45. Sun, F.H.; Li, J.; Yuan, Y.X.; Yan, Z.Y.; Liu, X.F. Effect of biological pretreatment with Trametes hirsuta yj9 on enzymatic hydrolysis of corn stover. Int. Biodeterior. Biodegrad. 2011, 65, 931-938. [CrossRef]

46. Saha, B.C.; Qureshi, N.; Kennedy, G.J.; Cotta, M.A. Biological pretreatment of corn stover with white-rot fungus for improved enzymatic hydrolysis. Int. Biodeterior. Biodegradation 2016, 109, 29-35. [CrossRef]

47. Alvira, P.; Tomás-Pejó, E.; Ballesteros, M.; Negro, M.J. Pretreatment technologies for an efficient bioethanol production process based on enzymatic hydrolysis: A review. Bioresour. Technol. 2010, 101, 4851-4861. [CrossRef] [PubMed]

48. Shi, J.; Chinn, M.S.; Sharma-Shivappa, R.R. Microbial pretreatment of cotton stalks by solid state cultivation of Phanerochaete chrysosporium. Bioresour. Technol. 2008, 99, 6556-6564. [CrossRef] [PubMed]

49. Baral, N.R.; Shah, A. Comparative techno-economic analysis of steam explosion, dilute sulfuric acid, ammonia fiber explosion and biological pretreatments of corn stover. Bioresour. Technol. 2017, 232, 331-343. [CrossRef]

50. Humbird, D.; Davis, R.; Tao, L.; Kinchin, C.; Hsu, D.; Aden, A.; Schoen, P.; Lukas, J.; Olthof, B.; Worley, M.; et al. Process. Design and Economics for Biochemical Conversion of Lignocellulosic Biomass to Ethanol; National Renewable Energy Laboratory: Golden, CO, USA, May 2011.

51. Martínez-Patiño, J.C.; Lu-Chau, T.A.; Gullón, B.; Ruiz, E.; Romero, I.; Castro, E.; Lema, J.M. Application of a combined fungal and diluted acid pretreatment on olive tree biomass. Ind. Crops Prod. 2018, 121, 10-17. [CrossRef]

52. Vasco-Correa, J.; Li, Y. Solid-state anaerobic digestion of fungal pretreated Miscanthus sinensis harvested in two different seasons. Bioresour. Technol. 2015, 185, 211-217. [CrossRef] [PubMed]

53. Vasco-Correa, J. Investigation of solid-state fungal pretreatment of Miscanthus for biofuels production. Ph.D. Thesis, The Ohio State University, Columbus, OH, USA, July 2017.

54. Sokhansanj, S.; Mani, S.; Turhollow, A.; Kumar, A.; Bransby, D.; Lynd, L.; Laser, M. Large-scale production, harvest and logistics of switchgrass (Panicum virgatum L.) — current technology and envisioning a mature technology. Biofuels Bioprod. Biorefin. 2009, 3, 124-141. [CrossRef]

55. Edwards, W. Estimating a Value for Corn Stover; Ag Decision Maker; Iowa State University Extension: Ames, IA, USA, June 2014.

56. Thoreson, C.P.; Webster, K.E.; Darr, M.J.; Kapler, E.J. Investigation of process variables in the densification of corn stover briquettes. Energies 2014, 7, 4019-4032. [CrossRef]

57. Sultana, A.; Kumar, A. Optimal configuration and combination of multiple lignocellulosic biomass feedstocks delivery to a biorefinery. Bioresour. Technol. 2011, 102, 9947-9956. [CrossRef]

58. Kargbo, F.; Xing, J.; Zhang, Y. Property analysis and pretreatment of rice straw for energy use in grain drying: A review. Agric. Biol. J. North. Am. 2010, 1, 195-200. [CrossRef] 
59. Lam, P.S.; Sokhansanj, S.; Bi, X.; Lim, C.J.; Naimi, L.J.; Hoque, M.; Mani, S.; Womac, A.R.; Ye, X.P.; Narayan, S. Bulk density of wet and dry wheat straw and switchgrass particles. Appl. Eng. Agric. 2008, 24, 351-358. [CrossRef]

60. Miao, Z.; Phillips, J.W.; Grift, T.E.; Mathanker, S.K. Measurement of mechanical compressive properties and densification energy requirement of Miscanthus x giganteus and switchgrass. Bioenergy Res. 2015, 8, $152-164$. [CrossRef]

61. Swanson, R.M.; Satrio, J.a.; Brown, R.C.; Platon, A.; Hsu, D.D. NREL Report: Techno-Economic Analysis of Biofuels Production Based on Gasification; National Renewable Energy Laboratory: Golden, CO, USA, November 2010.

62. Mani, S.; Tabil, L.G.; Sokhansanj, S. Effects of compressive force, particle size and moisture content on mechanical properties of biomass pellets from grasses. Biomass Bioenergy 2006, 30, 648-654. [CrossRef]

63. Searcy, E.; Hess, R. Uniform-Format Feedstock Supply System: A Commodity-Scale Design to Produce an Infrastructure-Compatible Biocrude from Lignocellulosic Biomass; Idaho National Laboratory: Idaho Falls, ID, USA, September 2010.

64. Dupont, C.; Chiriac, R.; Gauthier, G.; Toche, F. Heat capacity measurements of various biomass types and pyrolysis residues. Fuel 2014, 115, 644-651. [CrossRef]

65. Kumar, D.; Murthy, G.S. Impact of pretreatment and downstream processing technologies on economics and energy in cellulosic ethanol production. Biotechnol. Biofuels 2011, 4, 27. [CrossRef] [PubMed]

66. Alibaba.com. Available online: www.alibaba.com (accessed on 14 October 2018).

67. Davis, R.; Tao, L.; Tan, E.C.D.; Biddy, M.J.; Beckham, G.T.; Scarlata, C.; Jacobson, J.; Cafferty, K.; Ross, J.; Lukas, J.; et al. Process. Design and Economics for the Conversion of Lignocellulosic Biomass to Hydrocarbons: Dilute-Acid and Enzymatic Deconstruction of Biomass to Sugars and Biological Conversion of Sugars to Hydrocarbons; National Renewable Energy Laboratory: Golden, CO, USA, October 2013.

68. Saucedo-Castañeda, G.; Gutiérrez-Rojas, M.; Bacquet, G.; Raimbault, M.; Viniegra-González, G. Heat transfer simulation in solid substrate fermentation. Biotechnol. Bioeng. 1990, 35, 802-808. [CrossRef]

69. Weber, F.J.; Oostra, J.; Tramper, J.; Rinzema, A. Validation of a model for process development and scale-up of packed-bed solid-state bioreactors. Biotechnol. Bioeng. 2002, 77, 381-393. [CrossRef]

70. Shuler, M.L.; Kargi, F. Bioprocess. Engineering: Basic Concepts; Pearson: London, UK, 2014; ISBN 9781292025995.

71. Doran, P.M. Bioprocess. Engineering Principles; Academic Press: London, UK, 2013; ISBN 9780122208515.

72. Mitchell, D.A.; Berovič, M.; Krieger, N. (Eds.) Solid-State Fermentation Bioreactors - Fundamental of Desing and Operation; Springer: Heidelberg/Berlin, Germany, 2006; ISBN 978-3-540-31285-7.

73. Liu, G.; Zhang, J.; Bao, J. Cost evaluation of cellulase enzyme for industrial-scale cellulosic ethanol production based on rigorous Aspen Plus modeling. Bioprocess. Biosyst. Eng. 2016, 39, 133-140. [CrossRef]

74. Selig, M.; Weiss, N.; Ji, Y. Enzymatic Saccharification of Lignocellulosic Biomass: Laboratory Analytical Procedure (LAP); National Renewable Energy Laboratory: Golden, CO, USA, March 2008.

75. Hess, J.; Leitner, C.; Galhaup, C.; Kulbe, K.D.; Hinterstoisser, B.; Steinwender, M.; Haltrich, D. Enhanced formation of extracellular laccase activity by the white-rot fungus Trametes multicolor. In Biotechnology for Fuels and Chemicals; Humana Press: Totowa, NJ, USA, 2002; pp. 229-241.

76. Pandey, A. Solid-state fermentation. Biochem. Eng. J. 2003, 13, 81-84. [CrossRef]

77. Ulrich, G.D. A Guide to Chemical Engineering Process Design and Economics; Wiley: New York, NY, USA, 1984; ISBN 0471082767.

78. Brown, R.C. Biorenewable Resources: Engineering New Products from Agriculture; Wiley: New York, NY, USA, 2003; ISBN 9780813822631.

79. Aden, A.; Ruth, M.; Ibsen, K.; Jechura, J.; Neeves, K.; Sheehan, J.; Wallace, B.; Montague, L.; Slayton, A.; Lukas, J. Lignocellulosic Biomass to Ethanol Process. Design and Economics Utilizing Co-Current Dilute Acid Prehydrolysis and Enzymatic Hydrolysis for Corn Stover; National Renewable Energy Laboratory: Golden, CO, USA, June 2002.

80. Intelligen, Inc. SuperPro Designer-User's Guide; Intelligen, Inc.: Scotch Plains, NJ, USA, 2014; Available online: http:/ / www.intelligen.com/downloads/SuperPro_ManualForPrinting_v10.pdf (accessed on 24 July 2018).

81. IndexMundi Sugar Monthly Price-US Dollars per Kilogram. Available online: www.indexmundi.com (accessed on 6 January 2019).

82. Chevanan, N.; Womac, A.R.; Bitra, V.S.P.; Igathinathane, C.; Yang, Y.T.; Miu, P.I.; Sokhansanj, S. Bulk density and compaction behavior of knife mill chopped switchgrass, wheat straw, and corn stover. Bioresour. Technol. 2010, 101, 207-214. [CrossRef] 
83. Xu, C.; Ma, F.; Zhang, X.; Chen, S. Biological pretreatment of corn stover by Irpex lacteus for enzymatic hydrolysis. J. Agric. Food Chem. 2010, 58, 10893-10898. [CrossRef]

84. Balan, V. Current challenges in commercially producing biofuels from lignocellulosic biomass. ISRN Biotechnol. 2014, 2014, 1-31. [CrossRef]

85. Kazi, F.K.; Fortman, J.A.; Anex, R.; Hsu, D.D.; Aden, A.; Dutta, A.; Kothandaraman, G. Techno-economic comparison of process technologies for biochemical ethanol production from corn stover. Fuel 2010, 89, S20-S28. [CrossRef]

86. Maheshwari, R.; Bharadwaj, G.; Bhat, M.K. Thermophilic fungi: Their physiology and enzymes. Microbiol. Mol. Biol. Rev. 2000, 64, 461-488. [CrossRef]

87. Sokhansanj, S.; Kumar, A.; Turhollow, A.F. Development and implementation of integrated biomass supply analysis and logistics model (IBSAL). Biomass Bioenergy 2006, 30, 838-847. [CrossRef]

88. Cui, Z.; Shi, J.; Wan, C.; Li, Y. Comparison of alkaline- and fungi-assisted wet-storage of corn stover. Bioresour. Technol. 2012, 109, 98-104. [CrossRef]

89. Liu, S.; Li, X.; Wu, S.; He, J.; Pang, C.; Deng, Y.; Dong, R. Fungal pretreatment by Phanerochaete chrysosporium for enhancement of biogas production from corn stover silage. Appl. Biochem. Biotechnol. 2014, 1907-1918. [CrossRef]

90. Kaliyan, N.; Morey, R.V.; White, M.D.; Doering, A. Roll press briquetting and pelleting of corn stover and switchgrass. Trans. ASABE 2009, 52, 543-555. [CrossRef]

91. Kaliyan, N.; Morey, R.V.; Tiffany, D.G. Economic and environmental analysis for corn stover and switchgrass supply logistics. BioEnergy Res. 2015, 8, 1433-1448. [CrossRef]

92. Kaliyan, N.; Morey, R.V.; Schmidt, D.R. Roll press compaction of corn stover and perennial grasses to increase bulk density. Biomass Bioenergy 2013, 55, 322-330. [CrossRef]

93. Wendt, L.M.; Smith, W.A.; Hartley, D.S.; Wendt, D.S.; Ross, J.A.; Sexton, D.M.; Lukas, J.C.; Nguyen, Q.A.; Murphy, J.A.; Kenney, K.L. Techno-economic assessment of a chopped feedstock logistics supply chain for corn stover. Front. Energy Res. 2018, 6, 90. [CrossRef]

94. Agu, O.; Tabil, L.; Dumonceaux, T.; Agu, O.S.; Tabil, L.G.; Dumonceaux, T. Microwave-assisted alkali pre-treatment, densification and enzymatic saccharification of canola straw and oat hull. Bioengineering 2017, 4, 25. [CrossRef]

95. Chico-Santamarta, L.; Godwin, R.J.; Chaney, K.; White, D.R.; Humphries, A.C. On-farm storage of baled and pelletized canola (Brassica napus L.) straw: Variations in the combustion related properties. Energy 2013, 50, 429-437. [CrossRef]

96. Lu, D.; Tabil, L.G.; Wang, D.; Li, X.; Mupondwa, E. Comparison of pretreatment methods for wheat straw densification by life cycle assessment study. Trans. ASABE 2015, 58, 453-464. [CrossRef]

97. Kenney, K.L.; Cafferty, K.G.; Jacobson, J.J.; Bonner, I.J.; Gresham, G.; Hess, J.R.; Ovard, L.P.; Smith, W.A.; Thompson, D.N.; Thompson, V.S.; et al. Feedstock Supply System Design and Economics for Conversion of Lignocellulosic Biomass to Hydrocarbon Fuels; Idaho National Laboratory: Idaho Falls, ID, USA, September 2013.

98. Lu, X.; Withers, M.R.; Seifkar, N.; Field, R.P.; Barrett, S.R.H.; Herzog, H.J. Biomass logistics analysis for large scale biofuel production: Case study of loblolly pine and switchgrass. Bioresour. Technol. 2015, 183, 1-9. [CrossRef]

99. Martinkus, N.; Latta, G.; Morgan, T.; Wolcott, M. A comparison of methodologies for estimating delivered forest residue volume and cost to a wood-based biorefinery. Biomass Bioenergy 2017, 106, 83-94. [CrossRef]

100. Modenbach, A.A.; Nokes, S.E. Enzymatic hydrolysis of biomass at high-solids loadings—a review. Biomass Bioenergy 2013, 56, 526-544. [CrossRef]

101. Zhao, J.; Zheng, Y.; Li, Y. Fungal pretreatment of yard trimmings for enhancement of methane yield from solid-state anaerobic digestion. Bioresour. Technol. 2014, 156, 176-181. [CrossRef]

102. Zhao, J.; Ge, X.; Vasco-Correa, J.; Li, Y. Fungal pretreatment of unsterilized yard trimmings for enhanced methane production by solid-state anaerobic digestion. Bioresour. Technol. 2014, 158, 248-252. [CrossRef] [PubMed]

103. Song, L.; Yu, H.; Ma, F.; Zhang, X. Biological pretreatment under non-sterile conditions for enzymatic hydrolysis of corn stover. Bioresources 2013, 8, 3802-3816. [CrossRef] 
104. Akin, D.E.; Rigsby, L.L.; Sethuraman, A.; Morrison, W.H.; Gamble, G.R.; Eriksson, K.-E.L. Alterations in structure, chemistry, and biodegradability of grass lignocellulose treated with the white rot fungi Ceriporiopsis subvermispora and Cyathus stercoreus. Appl. Envir. Microbiol. 1995, 61, 1591-1598.

105. Shirkavand, E.; Baroutian, S.; Gapes, D.J.; Young, B.R. Combination of fungal and physicochemical processes for lignocellulosic biomass pretreatment-a review. Renew. Sustain. Energy Rev. 2016, 54, 217-234. [CrossRef]

106. Wang, Y.; Li, G.; Jiao, X.; Cheng, X.; Abdullah, M.; Li, D.; Lin, Y.; Cai, Y.; Nie, F. Molecular characterization and overexpression of mnp6 and vp3 from Pleurotus ostreatus revealed their involvement in biodegradation of cotton stalk lignin. Biol. Open 2019, 8, bio036483. [CrossRef]

107. Sharma, K.K.; Kuhad, R.C. Genetic transformation of lignin degrading fungi facilitated by Agrobacterium tumefaciens. BMC Biotechnol. 2010, 10, 67. [CrossRef]

108. Coconi-Linares, N.; Ortiz-Vázquez, E.; Fernández, F.; Loske, A.M.; Gómez-Lim, M.A. Recombinant expression of four oxidoreductases in Phanerochaete chrysosporium improves degradation of phenolic and non-phenolic substrates. J. Biotechnol. 2015, 209, 76-84. [CrossRef] [PubMed]

109. Davis, R.; Tao, L.; Scarlata, C.; Tan, E.C.D.; Ross, J.; Lukas, J.; Sexton, D. Process Design and Economics for the Conversion of Lignocellulosic Biomass to Hydrocarbons: Dilute-Acid and Enzymatic Deconstruction of Biomass to Sugars and Catalytic Conversion of Sugars to Hydrocarbons; National Renewable Energy Laboratory: Golden, CO, USA, March 2015.

110. Kazi, F.K.; Fortman, J.; Anex, R.; Kothandaraman, G.; Hsu, D.; Aden, A.; Dutta, A. Techno-Economic Analysis of Biochemical Scenarios for Production of Cellulosic Ethanol; National Renewable Energy Laboratory: Golden, CO, USA, June 2010.

(C) 2019 by the authors. Licensee MDPI, Basel, Switzerland. This article is an open access article distributed under the terms and conditions of the Creative Commons Attribution (CC BY) license (http:/ / creativecommons.org/licenses/by/4.0/). 